Boise State University

ScholarWorks

Management Faculty Publications and

Presentations

Department of Management

$1-1-2015$

\title{
Transforming the Legal Studies Classroom: Clickers and Engagement
}

Susan Park

Boise State University

Denise Farag

Linfield College 


\title{
Transforming the Legal Studies Classroom: Clickers and Engagement
}

\author{
Susan Park* and Denise Farag**
}

Teaching is not just delivering lectures but anything we might do that helps and encourages students to learn. ${ }^{1}$

\section{INTRODUGTION}

Envision your typical business law or legal environment of business classroom, filled with students. As class begins, most students are alert and attentive to the instructor. However, after class is under way, some students have diverted their attention elsewhere. A few are looking intently at their laptop screens, which contain material that may (or may not) be related to business law. Others are looking at their phones. While many are still listening to the instructor, a few might be whispering to neighbors, and one or two students even appear to be napping. Does this scene sound familiar? Now consider a different classroom, one in which every student in the class is looking at the screen at the front of the room, reading the same question, and thinking intently about the answer. The room is quiet. Imagine further that you, the instructor, can gather the students' answers to the question immediately and, with one click, present those results back to the class, in vivid graphics. When the results are displayed, the room is filled with a buzz as some students congratulate themselves on their correct answer, while others express dismay that they chose incorrectly. Their attention is on the question presented,

\footnotetext{
*Assistant Professor, Boise State University. This work was generously supported through a summer research grant from the Boise State University College of Business and Economics. The author thanks Boise State MBA Graduate Assistant Molly Haberl for her valuable research and analysis.

**Assistant Professor of Business Law, Linfield College.

${ }^{1}$ Ken Bain, What the Best College Teachers Do 173 (2004).

(c) 2015 The Authors

Journal of Legal Studies Education (๑) 2015 Academy of Legal Studies in Business
} 
which relates directly to the content of your course. In which classroom are students more engaged?

If you teach college students, chances are you would prefer the second classroom far more than the first. As professors of legal studies in business courses, we certainly do. Our desire to develop our teaching skills and increase student engagement in the classroom led us to conclude that our courses would improve by the introduction of a method of active learning, a personal response system ("clickers"), as an alternative to the traditional lecture. We quickly learned, however, as we began revising our courses to facilitate clicker use, that little literature specific to the legal studies discipline was available for help and suggestions. Much of the current literature regarding the use of clickers in the classroom consists of either general advice on implementing the technology or writing proper questions, not specific to a particular discipline, or it relates to the use of clickers in science-oriented classrooms, such as math, biology, and physics. ${ }^{2}$ Literature regarding the use of clickers in social science and humanities classrooms is less available; only a small number of articles relate to the use of active learning techniques in law or legal studies classrooms. ${ }^{3}$ A few articles address the use of clickers in law school classrooms, ${ }^{4}$ but only one practical article pertains specifically to legal studies courses designed for undergraduate students. ${ }^{5}$ The content in undergraduate legal studies courses may be relatively the same as that in law school courses, but the structure of the class and needs of the students are quite different. Lampe argues quite convincingly why legal studies courses

\footnotetext{
${ }^{2}$ See Catherine Easton, An Examination of Clicker Technology Use in Legal Education, 3 J. InFo. LAw \& ТЕсн. 1, 2-3 (2009) (noting that the number of articles relating to teaching law with clickers is minimal compared to those relating to physics and other science topics); Kumar Laxman, A Study on the Adoption of Clickers in Higher Education, 27 Australasian J. Educ. Tech. 1291-1303 (2011); Kelley Burton, Interactive PowerPoints: Is There Any Point in Giving Power to Students?, 11 MurdocH U. Electronic J.L. (2004), http://www.murdoch.edu.au/elaw/issues/v11n4/burton114.html.

${ }^{3}$ See Easton, supra note 2.

${ }^{4}$ See, e.g., Easton, supra note 2; Paul L. Caron \& Rafael Gely, Taking Back the Law School Classroom: Using Technology to Foster Active Student Learning, 54 J. Legal Educ. 551 (2004); Roger C. Park, Reflections on Teaching Evidence with an Audience Response System, 75 Brook. L. Rev. 1315 (2010); Samantha A. Moppett, Control-Alt-Incomplete? Using Technology to Assess "Digital Natives, "SuFfOLK U. L. Sch. Legal Stud. Research Paper Series, Research Paper 12-12, at 29-30 (Feb. 20, 2013).

${ }^{5}$ See Brian R. Levey, In-Class Polling: Less Teaching, More Learning?, in Teaching WITH Technology: The Stories Continue (Learning Technology Consortium, Mar. 16, 2011), http:/ /lcessays.files.wordpress.com/2011/03/01-levey.pdf.
} 
should be taught differently than legal subjects taught in law schools. ${ }^{6} \mathrm{He}$ observes that students in legal studies courses are future business practitioners and should learn about the law in such a way as to make better business decisions, not to be become minilawyers. ${ }^{7}$

This article fills the gap in the literature by addressing clicker use in legal studies courses. Our experience bears out the common finding that clickers are an excellent engagement tool. Although we use clickers in our classrooms in different ways, we have both found that they transformed our classroomswe and our students are more engaged in the material and in the process of teaching and learning. Building off the work of others, we have developed a framework for using clickers in undergraduate legal studies courses that identifies three general focus areas for clicker use: content focused, student focused, and instructor focused. Our intent is to add to the body of knowledge regarding clickers by giving legal studies faculty specific, practical suggestions for how they can transform their classrooms through the use of clickers. ${ }^{8}$ Although directed primarily toward business law faculty, we believe this article will also be useful for a more general teaching audience.

Part II begins with a brief description of personal response systems and how they are used. It also reviews the literature on student engagement and explains why it is an important element of learning. Part II concludes by addressing the link between clickers and engagement, particularly regarding the use of clickers in large-enrollment courses and in law school classes. Part III introduces a three-part framework of clicker use that can be applied to legal studies courses. This framework includes descriptions of the methods

\footnotetext{
${ }^{6}$ See Marc Lampe, A New Paradigm for the Teaching of Business Law and Legal Environment Classes, 23 J Leg Stud. Educ. 1 (2006).

${ }^{7}$ Id. at 2. See also Paul L. Frantz \& Alex H. Wilson, Student Performance in the Legal Environment Course: Determinants and Comparisons, 21 J Leg Stud. Educ. 225, 226 n. 5 (2004) (Although the skills required of undergraduate business students and graduate law students might be similar, significant differences between the two programs makes comparisons of the two "of limited value."); John R. Allison, The Role of Law in the Business School Curriculum, 9 J Leg Stud. Educ. 239, 240 (1991) (noting that undergraduate legal studies courses "serve unique and valuable purposes in the business school curriculum. They are, and should be, quite different from courses taught in law schools.").

${ }^{8}$ See Ian D. Beatty, Transforming Student Learning with Classroom Communications System, EduCAuSE Center for Applied Research (ICAR) 1, 7 (Feb. 3, 2004) ("The best way to help instructors adjust to their new roles is to provide mentoring and support by [clicker]-experienced teachers. A little scaffolding can go a long way.... Sharing questions between instructors, or even providing a library or model curriculum of predesigned question sets, can make a big difference to a new instructor trying to climb the steep [clicker] learning curve.").
} 
and strategies we used to introduce legal concepts to students in the classes we teach-Legal Environment of Business and Business Law I and II. This section also includes examples of questions we have developed to teach particular topics. Part IV discusses the challenges related to using clickers as a teaching tool, such as the time involved learning the technology, and related issues regarding drafting questions, with recommendations for overcoming them. This part also includes helpful, practical tips for faculty who are implementing clickers in their classrooms for the first time. Part V suggests new areas of research that could build upon the framework and concepts this article introduces.

\section{Clickers And Engagement}

Before discussing the use of clickers in legal studies courses, an explanation of what clickers are and how they are used is necessary. This part also addresses the connection between clickers, engagement, and student learning, with a brief emphasis on the particular challenges of teaching large enrollment courses.

\section{A. Clicker Overview}

Personal response systems are wireless handheld devices that permit students to respond to information requested by instructors. Scholars who have written about clickers have applied numerous labels to such devices, ${ }^{9}$ but for purposes of this article, we will use the term "clicker." Modern clicker systems generally consist of three components: (1) the clicker itself, (2) the instructor's receiver module through which clicker responses are captured, and (3) software that analyzes the resulting data. ${ }^{10}$ The clicker is a small handheld device that typically contains a ten-digit alpha-numeric keypad permitting students to transmit answer choices to the instructor's receiver. Each individual clicker has a unique signal, which corresponds to a particular user, so

\footnotetext{
${ }^{9}$ Robin H. Kay \& Ann LeSage, Examining the Benefits and Challenges of Using Audience Response Systems: A Review of the Literature, 53 Computers \& Educ. 819, 820 (2009) (identifying no less than twenty-six different labels that have been used for such devices, including audience response systems, classroom performance systems, personal response systems, electronic voting systems, student response systems, classroom response systems, and clickers).

${ }^{10}$ See, e.g., Maryfran Barber \& David Njus, Clicker Evolution: Seeking Intelligent Design, 6 LIFE SCI. Educ. 1 (2007); Ronald F. Premuroso et al., Does Using Clickers in the Classroom Matter to Student Performance and Satisfaction When Taking the Introductory Financial Accounting Course?, 26 IssuES IN AccT'G. Educ. 701, 705 (2011).
} 
that answers can be received on the instructor's antenna, or receiver. ${ }^{11}$ The receiver itself is small, similar in size to a USB storage device, and is used by connecting to a classroom or laptop computer. Clicker software is used to create and pose questions, and often can be integrated with commercial presentation software, such as PowerPoint. ${ }^{12}$ The clicker software permits the instructor to record and display student responses to the polled questions, in real time, in a variety of ways, including bar charts, histograms, and pie charts. The software also allows instructors to save and tally student classroom responses after class is over, and even upload or export this data directly into a learning management system such as Blackboard Learn. ${ }^{13}$ The manufacturer of the clicker system typically provides the software to instructors free of charge. ${ }^{14}$

A number of personal response systems are available for educational use. ${ }^{15}$ The three $^{16}$ primary systems on the market are offered by Turning Technologies, ${ }^{17}$ Quizdom, ${ }^{18}$ and iClicker. ${ }^{19}$ Many institutions make the selection of clicker systems on a campus-wide basis, while some leave the decision up to the individual instructor. As Table 1 summarizes, cost, compatibility with software and learning management systems, and ease of use

\footnotetext{
${ }^{11}$ Some clicker-based systems allow students to purchase a license and effectively use their smart devices as a clicker. For instance, Turning Technologies also offers students the option of purchasing a license rather than a clicker, which activates their smart device into a "virtual" clicker for classroom purposes. See TurningTechnologies.com, http://www. turningtechnologies.com/response-solutions/responseware (last visited Mar. 11, 2014).

${ }^{12}$ See, e.g., Barber \& Njus, supra note 10, at 2; Jane E. Caldwell, Clickers in the Large Classroom: Current Research and Best-Practice Tips, 6 CBE-Life Sc. Educ. 9, 10 (2007).

${ }^{13}$ Caldwell, supra note 12 , at 10 .

${ }^{14}$ Joe Calhoun et al., What Is a Classroom Response System: Technical Details, Pedagogy in Action, http://serc.carleton.edu/44295 (last visited Mar. 11, 2014).

${ }^{15}$ See Barber \& Njus, supra note 10, at 3-7, for a detailed comparison of the various systems.

${ }^{16}$ In August, 2013, Turning Technologies completed the acquisition of a rival fourth classroom response system, from eInstruction, that was popular with higher education institutions. While there were no immediate plans to discontinue eInstruction clickers, Turning Technologies did announce that there would be a deemphasis on eInstruction clickers moving forward. Turning Technologies Acquires eInstruction, 20 ELEC. EDUC. REPORT 18 (2013), available at http://www.electroniceducationreport.com/content/september-16-2013volume-20-number-18.

${ }^{17}$ Turning Technologies, supra note 11.

${ }^{18}$ Qwizdom, http:// qwizdom.com (last visited Mar. 11, 2014).

${ }^{19}$ iClicker, http:/ /iclicker.com (last visited Mar. 11, 2014).
} 
Table 1: Comparison of Clicker Systems

\begin{tabular}{|c|c|c|c|}
\hline & Turning Technologies & iClicker & Quizdom \\
\hline $\begin{array}{l}\text { General } \\
\text { Information }\end{array}$ & $\begin{array}{l}\text { Company founded in } \\
\text { 2002. Recently } \\
\text { acquired rival } \\
\text { eInstruction. Has } \\
\text { largest share of } \\
\text { higher education } \\
\text { clicker market. }\end{array}$ & $\begin{array}{l}\text { Invented by four } \\
\text { physicists at } \\
\text { University of } \\
\text { Illinois. } \\
\text { Company } \\
\text { purchased by } \\
\text { MacMillan } \\
\text { Publishing in } \\
2005 \text {. }\end{array}$ & $\begin{array}{l}\text { Company } \\
\text { established in } \\
1984 \text { by a } \\
\text { science } \\
\text { teacher } \\
\text { wanting to } \\
\text { improve "in } \\
\text { the moment" } \\
\text { learning. }\end{array}$ \\
\hline Receiver Cost & $\begin{array}{l}\text { One free per } 50 \\
\text { clickers; otherwise } \\
\$ 99 \text {. }\end{array}$ & $\begin{array}{l}\text { One free per } 100 \\
\quad \text { clickers; } \\
\text { otherwise } \\
\$ 300 .\end{array}$ & $\begin{array}{l}\text { One free per } 100 \\
\text { clickers; } \\
\text { otherwise } \\
\$ 400 .\end{array}$ \\
\hline Clicker Cost & $\begin{array}{l}\text { One-time cost: } \$ 28-\$ 58 \\
\text { new (depending on } \\
\text { model). }\end{array}$ & $\begin{array}{l}\text { One-time cost: } \\
\quad \$ 38-\$ 48 \text { new. }\end{array}$ & $\begin{array}{l}\text { One-time cost: } \\
\quad \$ 36-\$ 48 \text { new. }\end{array}$ \\
\hline $\begin{array}{l}\text { Power Point } \\
\text { (PP) } \\
\text { Compatibility }\end{array}$ & $\begin{array}{l}\text { Complete integration } \\
\text { with PP. }\end{array}$ & $\begin{array}{l}\text { Compatible with } \\
\text { PP. }\end{array}$ & $\begin{array}{l}\text { Compatible with } \\
\text { PP. }\end{array}$ \\
\hline $\begin{array}{l}\text { Learning } \\
\text { Management } \\
\text { System (LMS) } \\
\text { Compatibility }\end{array}$ & $\begin{array}{l}\text { Integrates with } \\
\text { BlackBoard Learn; } \\
\text { clicker scores can } \\
\text { load directly into } \\
\text { grade center. }\end{array}$ & $\begin{array}{l}\text { Integrates with } \\
\text { Blackboard } \\
\text { Learn. }\end{array}$ & $\begin{array}{l}\text { Compatible with } \\
\text { Blackboard } \\
\text { Learn; results } \\
\text { export to } \\
\text { Excel for } \\
\text { upload to } \\
\text { grade center. }\end{array}$ \\
\hline $\begin{array}{r}\text { Ease of Use: } \\
\text { Instructor }\end{array}$ & $\begin{array}{l}\text { Slight to moderate } \\
\text { learning curve. }\end{array}$ & $\begin{array}{l}\text { Slight learning } \\
\text { curve. }\end{array}$ & $\begin{array}{l}\text { Slight to } \\
\text { moderate } \\
\text { learning } \\
\text { curve. }\end{array}$ \\
\hline $\begin{array}{l}\text { Ease of Use: } \\
\text { Student }\end{array}$ & $\begin{array}{l}\text { Easy to learn; } \\
\text { sometimes students } \\
\text { not certain their } \\
\text { answers have been } \\
\text { recorded. }\end{array}$ & $\begin{array}{l}\text { Easy to learn; } \\
\text { light notifies } \\
\text { students when } \\
\text { answers have } \\
\text { been } \\
\text { recorded. }\end{array}$ & $\begin{array}{l}\text { Slight learning } \\
\text { curve. }\end{array}$ \\
\hline Website & $\begin{array}{l}\text { turningtechnologies. } \\
\text { com }\end{array}$ & iclicker.com & quizdom.com \\
\hline
\end{tabular}

are factors instructors, who are able to choose between the available options, might consider. ${ }^{20}$

\footnotetext{
${ }^{20}$ See infra text accompanying notes 121-23 for further discussion about institutional support and the issues faculty, who are deciding whether to adopt clickers, should consider.
} 
While not the focus of this article, it is worth noting briefly the availability of other polling alternatives that do not rely on separate clicker systems. Classroom polling can also now be done with the use of mobile phones or web-enabled devices (e.g., smart phones, tablets, or laptops). ${ }^{21}$ Instructors create polls using an online polling app, and students vote by text messaging responses or voting online. The three clicker-based systems, Turning Technologies, iClicker, and Quizdom, offer alternative software polling options whereby smart devices can be used to query students. In addition, a number of other companies offer non-clicker-based polling options, with Poll Everywhere, ${ }^{22}$ Socrative, ${ }^{23}$ GoSoapBox, ${ }^{24}$ and Top Hat ${ }^{25}$ being among the most popular. An obvious advantage to using a mobile phone or web-enabled device is that it eliminates the need for a separately purchased clicker, which can be a cheaper solution for students. However, classroom polling with mobile phones and web-enabled devices is not necessarily free. More commonly, either the institution pays a certain amount per professor or per student, or the student has to pay a modest fee. Too, there are disadvantages to using alternative polling options. Some instructors might find that the students' use of laptops and smart phones poses a greater potential for distraction during nonpolling times than the non-web-enabled clicker system. ${ }^{26}$ Instructors might also prefer hardware clicker systems because some students may not have access to mobile devices, instruction might occur in spaces without Wi-Fi access, or hardware systems often include advanced reporting features not available in online polling. ${ }^{27}$ Regardless of the means of polling, either by hardware clicker systems or by polling software utilizing smart devices or laptops, the clicker questions proposed in Part III should be capable of being adapted as the instructor sees fit.

\footnotetext{
${ }^{21}$ See generally, Peter K. Dunn et al., Instructor Perceptions of Using a Mobile-Phone-Based Free Classroom Response System in First-Year Statistics Undergraduate Courses, 43 Int'L J. Math. Educ. Sci. \& Tech., 1041, 1043 (2012).

${ }^{22}$ Poll Everywhere, http://www.polleverywhere.com (last visited Feb. 4, 2014).

${ }^{23}$ Socrative, http://www.socrative.com (last visited Feb. 4, 2014).

${ }^{24}$ GoSoapBox, http://www.gosoapbox.com (last visited Feb. 4, 2014).

${ }^{25}$ Top Hat, https://tophat.com (last visited Feb. 4, 2014).

${ }^{26}$ See infra text accompanying note 109 for further discussion about the possible disadvantages of using smart devices in the classroom.

${ }^{27} \mathrm{~A}$ comparison of the strengths and weaknesses of clicker-based compared to web-based polling systems is an interesting area of further research, as we suggest in Part V, infra.
} 


\section{B. Student Engagement}

In 1987, in an effort to identify best practices in undergraduate education, scholars Arthur Chickering and Zelda Gamson published the influential essay Seven Principles for Good Practice in Undergraduate Education. ${ }^{28}$ One of the seven principles of good practice they identified is to encourage "active learning," 29 which has been broadly defined as "anything that students do in a classroom other than merely passively listening to an instructor's lecture." ${ }^{30}$ Active learning techniques include group discussions, writing exercises, simulations, demonstrations, and Socratic dialogs. ${ }^{31}$ An abundance of research suggests that the use of active learning methods in the classroom promotes student learning and engagement in the subject matter of the course. ${ }^{32}$ However, getting students to participate in certain active learning techniques, such as asking students questions related to the lecture and having them respond in class, can be problematic. ${ }^{33}$ Clickers offer an excellent approach to engaging students in active learning, which is especially important to a generation that has grown up with technology in all aspects of their lives.

Clickers have been shown to improve student engagement, sometimes dramatically. ${ }^{34}$ Clickers can be used to break up the tedium of lecture, gauge

\footnotetext{
${ }^{28}$ Arthur Chickering \& Zelda Gamson, Seven Principles for Good Practice in Undergraduate Education, 39 AAHE Bull. 3 (1987).

${ }^{29} I d$. at 4 .

${ }^{30}$ Donald R. Paulson \& Jennifer L. Faust, Active Learning for the College Classroom, 9 J. ExCELLENCE C. Tch. 3, 4 (1988).

${ }^{31} I d$.

${ }^{32}$ See, e.g., John Barnett, Implementation of Personal Response Units in Very Large Lecture Classes: Student Perceptions, 22 Australasian J. Educ. Tech. 474 (2006); Beatty, supra note 8; Caron \& Gely, supra note 4.

${ }^{33}$ Judith Morse et al., Clicking Our Way to Class Discussion, 3 Aм. J. Bus. Educ. 99, 99-100 (2010) (students may not participate because of a fear of ridicule, lack of self-confidence or preparation, and classroom culture).

${ }^{34}$ See, e.g., Margie Martyn, Clickers in the Classroom: An Active Learning Approach, 2 EducAuse Q. 71 (2007); Kalyani Premkumar \& Cyril Coupal, Rules of Engagement-12 Tips for Successful Use of "Clickers" in the Classroom, 30 Med. TCHR. 146 (2008); Steven A. Yourstone et al., Classroom Questioning with Immediate Electronic Response: Do Clickers Improve Learning?, 6 Dec. SaI. J. InNovative Educ. 75 (2008). Additionally, Professor Park developed and administered two surveys regarding clickers for students to complete and submit anonymously during approximately the last two weeks of class over the course of five semesters. See Appendix (Table 1: Engagement Survey
} 
student understanding of material and difficult concepts, and indicate areas of student misunderstanding and confusion. Clickers give every student, even those who are uncomfortable participating in class, an opportunity to provide input. " $[\mathrm{T}]$ he anonymity of responding with a clicker guarantees near or total participation." ${ }^{35}$ They are also a more effective teaching tool than asking for a simple show of hands, for several important reasons. They allow students to respond to complex questions ${ }^{36}$ and also allow for "rapid presentation" of the statistical results of student responses, which raised hands simply cannot do. ${ }^{37}$ Moreover, asking students to raise their hands to signal comprehension or calling on one student to determine his or her understanding of material often fail to provide the important feedback instructors are looking for. "The difficulty with the former approach is that there is no opportunity to discover if the students 'get it' until the final exam; the difficulty with the latter approach is that the one unlucky student is not necessarily representative of the class's collective understanding." 38

Students who respond to instructor questions through clickers are able to give an instructor immediate feedback on their understanding of the material, which then dictates whether additional time is needed on a particular topic. ${ }^{39}$ Instructors who use clickers have reported a dramatic increase in attendance $^{40}$ (although improvement could depend upon whether clickers are used for grading purposes). Clickers can help instructors determine whether

and Table 2: Clicker Survey). Both surveys indicate that a large majority of students believe that clicker questions engage them in the material. For instance, 374 students either strongly agreed (72 percent) or agreed (22 percent) that "clicker questions encourage me to be more engaged in the classroom process."

${ }^{35}$ Martyn, supra note 34 , at 72 .

${ }^{36} I d$. ("You can imagine yourself saying, 'Okay, put up your right hand for A, left hand for B, both hands for C, and stand up for D.").

${ }^{37}$ Anne M. Cleary, Using Wireless Response Systems to Replicate Behavioral Research Findings in the Classroom, 25 Teaching Psych. 42, 43 (2008). Cleary also suggests that students report finding the displayed results "more compelling" than a show of hands. Id.

${ }^{38}$ Caron \& Gely, supra note 4, at 29.

${ }^{39} \mathrm{Id}$.

${ }^{40}$ Easton, supra note 2, at 6 (summarizing two reports that showed an increase in attendance and exam scores after adoption of clicker technology); Douglas J. Lincoln, Student Response Systems Adoption and Use in Marketing Education: A Status Report, 19 Mктg. Educ. Rev. 25, 26 (2009); Caldwell, supra note 12, at 13. 
students have come to class prepared ${ }^{41}$ and have been shown to improve student test scores and overall grades. ${ }^{42}$

Much of the literature also suggests that students prefer classrooms with clickers. For instance, Easton reports that " $[t]$ he vast majority of studies ... report positive student feedback in response to clicker use. . . In a survey of 1,500 clicker users Trees and Jackson found: Most students think that clickers give them valuable feedback. Many students enjoy the interaction that clickers provide. ${ }^{23}$ Instructors who use clickers have also related that they gain value from learning about students' opinions, which can promote richer classroom discussion. ${ }^{44}$ Moreover, the use of clickers can create a sense of classroom community and "change the atmosphere of lectures" to one in which students are "invested" in the questions and thus more likely to attend class, retain the information, and succeed on exams. ${ }^{45}$ Even the simple act of taking attendance can be fun and engaging, thus helping to create a sense of community. ${ }^{46}$ Finally, the use of clickers in the classroom encourages student-faculty contact and student cooperation. Clicker responses compel students "to recognize the many possibilities in answering a particular problem and to compare their answers with those of other students. The ensuing dialogue furthers the principle of increasing student-to-student interaction." 47

\footnotetext{
${ }^{41}$ Klaus Woelk, Optimizing the Use of Personal Response Device (Clickers) in Large-Enrollment Introductory Courses, 85 J. Chem. Educ. 1400, 1401 (2008) ("One simple, well-chosen, and appropriately graded question is usually sufficient to assure a minimum level of preparedness for the topics covered in class.").

${ }^{42}$ Lincoln, supra note 40 , at 26 (summarizing several studies that showed improvement on exams).

${ }^{43}$ Easton, supra note 2, at 7 (citations omitted). See also Lincoln, supra note 40, at 26. Our own experience shows this as well, as described in more detail in Part III infra.

${ }^{44}$ Woelk, supra note 41, at 1401-02 ("Clickers provide the instructor with a unique opportunity to create initial interest and additional motivation by polling on common knowledge, opinions, estimates, or guesses... The largest initial interest, and thus motivation for students to engage in the subject matter, is generated by polls on common misconceptions or controversial issues.").

${ }^{45}$ Caldwell, supra note 12, at 12-13. See also Amy Shapiro, An Empirical Study of Personal Response Technology for Improving Attendance and Learning in a Large Class, 9 J. Scholarship Tch. \& LearnING, 13 (2009).

${ }^{46}$ Woelk, supra note 41 , at $1400-01$.

${ }^{47}$ Caron \& Gely, supra note 4 , at 36-37.
} 
In addition to the above benefits of using clickers, they can also help instructors manage the unique challenges presented by large enrollment courses. Many undergraduate legal studies courses are indeed large enrollment classes, which have been described as the "bane of active learning pedagogy." ${ }^{48}$ According to Trees and Jackson, large lecture classes suppress student learning because they (1) limit opportunity to practice activities that promote higher-order learning, (2) limit instructors' ability to give feedback, (3) limit opportunities for student involvement, (4) shape and reinforce an expectation that students are simply passive learners, (5) reduce students' sense of responsibility for interacting in class, and finally (6) create a reluctance to participate and speak in class. ${ }^{49}$

Large lecture courses present instructors with practical limitations as well. The classrooms themselves, often with auditorium seating, create an impersonal atmosphere in which interactive learning is difficult. ${ }^{50}$ The larger number of students means that they are often strangers to each other, increasing their unwillingness to participate in class and interact with the instructor. "Instructors who teach large courses face additional challenges compared with smaller, seminar-style courses: It is more difficult to track attendance, and students who miss class may have trouble learning course material and keeping up with assigned readings. ${ }^{, 1}$

Many of these challenges can be eased by using clickers in large classes. As Trees and Jackson point out,

Theoretically, [clickers] could transform the pedagogy of the large enrollment course. They provide an opportunity for all students in the classroom to interact and contribute their viewpoint, encourage students to actively respond to ideas and questions, and give instructors an opportunity to assess student understanding at the moment. Clicker questions can be used to accomplish a variety of pedagogical goals: assess students' understanding, give feedback on

\footnotetext{
${ }^{48}$ April R. Trees \& Michele H. Jackson, The Learning Environment in Clicker Classrooms: Student Processes of Learning and Involvement in Large University-Level Courses Using Student Response Systems, 32 Learning, Media \& Tech. 21, 21 (2007).

${ }^{49} I d$.

${ }^{50} I d$. at $22-23$.

${ }^{51}$ Stefanie Mollborn \& Angel Hoekstra, "A Meeting of Minds": Using Clickers for Critical Thinking and Discussion in Large Sociology Classes, 38 Teaching Soc. 18, 19 (2010). Mollborn and Hoekstra also suggest that facilitating other learning goals, such as student engagement and critical thinking, is difficult in large classrooms.
} 
learning, initiate a classroom discussion, stimulate student activity, explore students' responses, and customize instruction. ${ }^{52}$

Thus, students and faculty who use personal response systems in undergraduate courses, especially those with larger numbers of students, clearly may benefit from this pedagogical tool. However, legal studies instructors who wish to incorporate clickers into their classrooms have little literature specific to their discipline to which they can turn for help. Only a few articles relate to the use of clickers in law classes. ${ }^{53}$ Caron and Gely published an early article in the Journal of Legal Education in 2004 in which they advocated for the use of clickers in law school courses:

In our experience... [clickers] can be used to help students better appreciate the nuances of the law.... The opportunities for active learning thus are enormous. First, students can visualize the diverse set of views and arguments that can be made for any particular response. This is particularly helpful in getting the students away from the "only one answer" model and in forcing them to reassess the strength of their initial responses. Second, by "forcing" students to commit to an answer by recording their choices through the handheld devices, the CPS [classroom performance system] gives all students (even those who otherwise would not volunteer in class) the opportunity to voice their choices. Third, the range of possible answers serves as a springboard to a dynamic classroom discussion. For example, a professor could begin the discussion with the weakest of the alternative answers and force the students to identify the defects in that choice. The professor then could progressively work through the other answers, finishing with the "best" answer for that particular context. ${ }^{54}$

Like Caron and Gely, we are also convinced that clickers are a useful tool for engaging students in legal studies courses, especially in large lecture halls. However, articles about using clickers in law school teaching are helpful but do not address the student qualities and concerns that are unique to undergraduate business students in legal studies courses. ${ }^{55}$ Therefore, we

\footnotetext{
${ }^{52}$ Trees \& Jackson, supra note 48, at 24-25. See also Mollborn \& Hoekstra, supra note 51, at 19; Caldwell, supra note 12; Woelk, supra note 41; Michael K. Salemi, Clickenomics: Using a Classroom Response System to Increase Student Engagement in a Large-Enrollment Principles of Economics Course, 40 J Econ. Educ. 385 (2009).

${ }^{53}$ See Easton, supra note 2, at 13 (suggesting very little pedagogical development of clicker use in the discipline of law). See also generally Park, supra note 4.

${ }^{54}$ Caron \& Gely, supra note 4, at 30-31.

${ }^{55}$ See Lampe, supra note 6; Frantz \& Wilson, supra note 7; Allison, supra note 7.
} 
turn now to a discussion of our own legal studies courses and how we have adapted them to use clickers.

\section{Clickers in Legal Studies Courses}

The literature is replete with articles discussing how university instructors might use clickers, either generally or within various disciplines. ${ }^{56}$ Suggestions for clicker use range from articles providing practical tips for using the technology and drafting specific questions ${ }^{57}$ to papers that present a broader framework that categorizes the ways in which clickers might be used. ${ }^{58}$ Professor Catherine Easton, in An Examination of Clicker Technology Use in Legal Education, one of the few articles that address the use of clickers in law-related courses, suggests eight possible uses for clickers in law courses. ${ }^{59}$ These include assessing prior understanding, testing student completion and comprehension of the required reading, providing formative feedback, "breaking up" lecture, assessment, promoting peer learning, and managing attendance. ${ }^{60}$ Michael Salemi organizes his clicker strategies for use in a Principles of Economics course under the following five headings: Sampling Student Opinion, Asking Are-You-With-Me Questions, Acquiring Economic Data from Students, Peer Instruction Activities, and Games and

\footnotetext{
${ }^{56}$ Many clicker-related articles also describe surveys regarding clicker use. See, e.g., Lincoln, supra note 40; Gregory A. DeBourgh, Use of Classroom "Clickers" to Promote Acquisition of Advanced Reasoning Skills, 8 Nurse Educ. Prac. 76 (2008); Shawn M. Keough, Clickers in the Classroom: A Review and a Replication, 36 J. Mgmt. Educ. 822 (2012); Jason Harlow et al., What's All the Clicking About? A Study of Classroom Response System Use at the University of Toronto, unpublished manuscript, http:/ / www.google.com/url?sa $=\mathrm{t} \& \mathrm{rct}=\mathrm{j} \& \mathrm{q}=\& \mathrm{esrc}=\mathrm{s} \&$ source $=$ web\&cd $=1 \&$ ved $=0 \mathrm{CC} 4 \mathrm{QFj}$ AA\&url=http \%3A\%2F\%2Ffaraday.physics.utoronto.ca \% 2FPVB $\%$ 2FHarrison \% 2FClickers \%2FClickers_PVB.pdf\&ei=HYhUUqWNOu_ZigLN_4GoDw\&usg=AFQjCNF8w8pSzuszZNRS1 fTQvnL6sF6BIg\&bvm=bv.53760139,d.cGE2008 (last visited November 6, 2014).

${ }^{57}$ See, e.g., DeBourgh, supra note 56; Caldwell, supra note 12; Premkumar \& Coupal, supra note 34; Harlow et al., supra note 56.

${ }^{58}$ See, e.g., Woelk, supra note 41; Ian D. Beatty et al., Designing Effective Questions for Classroom Response System Teaching, 74 Aм. J. Phys. 31 (2006).

${ }^{59}$ Easton, supra note 2.

${ }^{60} I d$. at 4-6. Caron and Gely also suggest that clickers appeal to a variety of teaching styles. "The CPS [classroom performance system] is an effective tool to reach the mix of talents and learning styles of students because it allows the professor to draft different types of questions to target different types of thinking and thus different types of learners." Caron \& Gely, supra note 4, at 32.
} 
Simulations. ${ }^{61}$ Caldwell lists nine general uses, including increasing interaction, assessing preparation, and assessment, both formal and informal. ${ }^{62}$

Each of these approaches is instructive. Ultimately, we agree with Trees and Jackson, who wisely conclude that there is no uniform way to use clickers in the classroom. ${ }^{63}$ Instructors who are considering adopting clickers in their classrooms are well advised to review the literature, as the uses of clickers are vast. Indeed, our own experience reflects this; although we both adopted clickers for largely the same reasons, our individual styles and methodology differ.

Professor Park has used clickers as an integral part of her classroom teaching since 2009, primarily as a method for conveying information and giving students an opportunity to practice application of the law. ${ }^{64}$ Her classroom approach consists of "minilectures" centering on student responses to clicker questions. She removed less demanding material from classroom discussion altogether, requiring students to learn that material on their own outside of class and then covering it briefly, if at all, during an exam review session. This frees up considerable classroom time to cover more complex topics.

Professor Farag has used clickers as a supplement to traditional lecture and also as a tool for assessing student preparation prior to in-class lectures since 2011. ${ }^{65}$ Sustaining student interest for long class periods (one hour and forty minutes), even with individual and small group exercises included, can prove challenging. Professor Farag's initial motivation for implementing clickers, by "chunking" the material into minisessions by introducing clicker slides between discrete topics, was to enhance student interest and involvement during class. She quickly realized that clickers could be used as

\footnotetext{
${ }^{61}$ Salemi, supra note 52, at 389-99.

${ }^{62}$ Caldwell, supra note 12 , at 10-11. The other uses she lists are finding out more about students, doing practice problems, "to guide thinking, review, or teach," conducting experiments or "illustrate human response," and finally, to "make lecture fun." Id. See also Woelk, supra note 41, who developed two broader categories of clicker use: "I Am" and "I Do." As Woelk explains, “[e]xamples of 'I Am' clicker use would be to indicate attendance, preparation, and interest. Examples of 'I Do' clicker use are indications of what students have learned, what they understand, and what they can apply." Id. at 1403.

${ }^{63}$ Trees \& Jackson, supra note 48, at 27.

${ }^{64}$ Professor Park uses clickers in both undergraduate Legal Environment of Business classes and MBA level legal studies courses at Boise State University.

${ }^{65}$ Professor Farag uses clickers in her Business Law I and Business Law II classes at Linfield College.
} 
a classroom tool in myriad other ways to enhance student preparation and engagement.

We grade student work via clickers differently. Students in Professor Park's classes earn participation points for engaging in class via clickers and can also earn the occasional extra credit point for answering particular questions correctly (primarily to motivate students to do the reading), but clickers are not used for assessment purposes. Students in Professor Farag's classes can earn up to twenty points ( 5 percent of their grade) from prelecture clicker quizzes but are not awarded participation points for clicker responses during lectures.

Despite the differences in our approach, the similarity of our course content has allowed us to develop a common structure for how other legal studies faculty might use clickers. The framework we have developed borrows from the literature reviewed in previous sections, combining several of the suggestions in a new way that is, at least in part, designed to encourage mastery of the rules of law and subsequent legal analysis thatt is typically taught in legal studies courses. We organize our clicker strategies under three broad headings:

1. Content focused (using clickers to help students learn basic content and master legal analysis);

2. Student focused (using clickers to create a sense of community and help build student self-confidence); and

3. Instructor focused (using clickers for purposes of classroom management and assessment).

Each of these three broad categories overlaps significantly.

\section{A. Content-Focused Use of Clickers}

Legal studies in business courses typically require students to learn general rules of law and then apply those rules to presented issues to engage in critical thinking and solve the problems. Using clickers in the classroom can be tremendously beneficial to students as they learn this method of critical thinking.

Initially, we use clickers simply to determine whether students are prepared for class. For instance, at the beginning of a new chapter or unit, Professor Park will often start the classroom discussion on that topic by asking students a question similar to the one presented in Figure 1. 


\section{I read Chapter 5.}

1. Yes

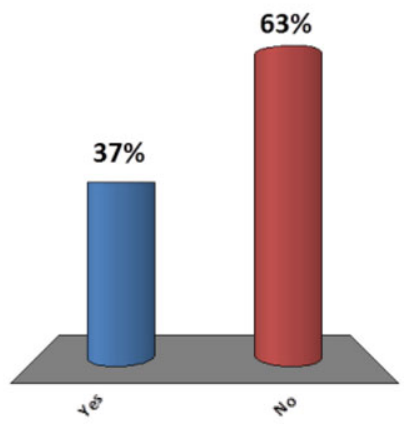

Figure 1: Sample Preparation Question

This type of question ${ }^{66}$ is an example of what Easton refers to as "assessment of prior learning." ${ }^{67}$ Knowing whether most students have read the material can be helpful to an instructor, who may then decide to do a quick minilecture on the topic to help those unprepared students get up to speed. As discussed more fully below in Section III.C (Instructor-Focused Clicker Use), Professor Farag gets a pulse on how well prepared her students might be for class by conducting a prelecture clicker quiz on assigned chapter questions. Because modest points are awarded, quiz results show that the overwhelming majority of students make an attempt to engage the material before lecture. ${ }^{68}$

\footnotetext{
${ }^{66}$ The instructor response to this question can help to create a sense of fun and community in the classroom. On occasion Professor Park has learned that less than 50 percent of the class read the material to be covered in class that day and responds with a dramatic stab of an imaginary dagger through her heart. This typically elicits some laughter, which creates a good segue into a brief discussion about why reading the material before class is beneficial. See also infra text accompanying notes $87-88$ for further discussion of using clickers to create a sense of community.

${ }^{67}$ See, e.g., Easton, supra note 2, at 4; Caroline Elliott, Using a Personal Response System in Economics Teaching, 1 Int'l Rev. Econ. Educ. 80, 80-81 (2003) (testing students' understanding of previously covered material through the use of a personal response system allows the instructor to learn how much students have retained from previous courses as well as to conduct a brief review of material and follow-up).

${ }^{68}$ In the last two semesters of Business Law I and Business Law II, out of the possible twenty points awarded for prelecture clicker quizzes, 66.4 percent of students earned nineteen to twenty
} 
If a person adversely possesses real property, s/he eventually:

\section{Pays a reasonable price for the property \\ 2. Obtains squatters rights according to the state's Homestead Act \\ 3. Gains ownership of the property $\mathrm{w} / \mathrm{o}$ paying for it}

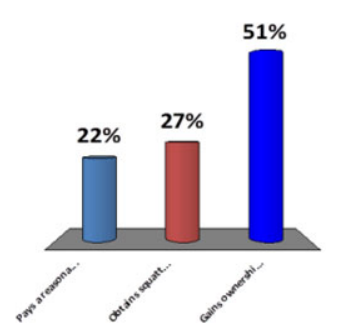

Figure 2: Question on Adverse Posession

Next, clickers can be used to ask questions about rules of law, identification of which is one of the first steps required in basic legal analysis. The questions can be either true/false or multiple choice. The topics that could be covered are limited only by one's syllabus. For example, when covering Property Law, Professor Park asks the question presented in Figure 2 about adverse possession.

In Professor Farag's Business Law I class, an example of a basic remedy question is shown in Figure 3.

Over time, we have learned that asking these types of basic content questions through the use of clicker slides is only a small step beyond typical lecture-it does not transform the classroom to a truly active learning environment. In other words, too many of these types of slides can cause students to disengage because, frankly, such questions tend to be boring. While useful, their use should be limited. Instead, we believe that a better approach is to focus on the second step in legal analysis-application of the law to solve a legal problem. We generally assume that students have already familiarized themselves with the content when they come into the classroom, so we spend more time on presenting questions that require students to engage in critical thinking by applying the law they learned outside of the classroom to scenarios they are presented with in class. With practice and experience, instructors

points, 15 percent of students earned seventeen to eighteen points, 11.2 percent of students earned fifteen to sixteen points, 4.7 percent of students earned thirteen to fourteen, and 2.8 percent of students earned less than thirteen points. 


\section{Equitable remedy ordering a party} to perform as promised.
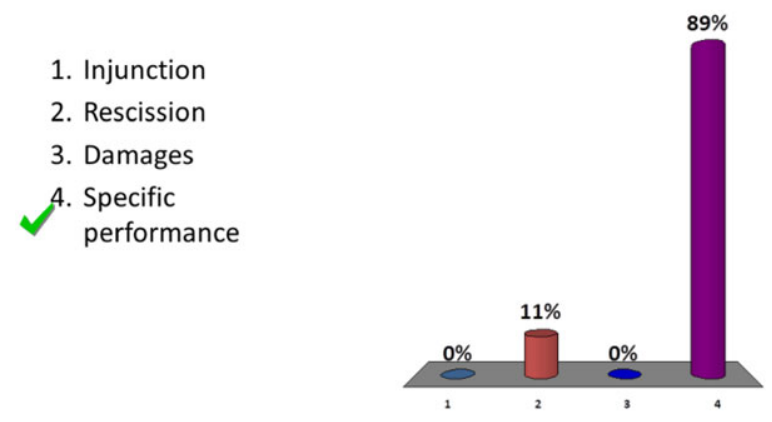

Figure 3: Basic Remedy Question

who regularly use clickers in the classroom will soon learn to identify those topics that elicit positive student response. ${ }^{69}$ Indeed, we have both identified multiple such instances. Below are a few of many examples of how this might be done.

In Professor Farag's class, the following question on torts (see Figure 4) ${ }^{70}$ helps students sort through possible defenses to the tort of defamation and opens up a discussion about the defense of privilege.

When Professor Park covers partnership law in class, particularly the section in which students learn about the partnership's and individual partners' liability for torts committed by a partner, she illustrates the points by using a hypothetical landscaping business, ABC Landscaping, owned by partners Adam, Bob, and Charlie. The stage is set with the informational (nonclicker) slide presented in Figure 5.

The three slides that follow this scenario increase in difficulty and provide an excellent starting point for talking about the liability consequences of being in a partnership (see Figures 6 through 8 ).

\footnotetext{
${ }^{69}$ See Harlow et al., supra note 56, at 3 ("We asked faculty who were new to clickers about what changes they might make to their pedagogy if they were to use clickers in the future. Most responded they would put more effort into formulating questions, including more conceptual questions as opposed to fact-checking, and encourage discussion before the vote.").

${ }^{70}$ Question authored by Marianne M. Jennings, In Defense of the Sage on the Stage: Escaping from the "Sorcery" of Learning Styles and Helping Students, 29 J. Legal Stud. Educ. 191, 222 (2012).
} 
Congressman Joe Wilson shouted out "You lie!" to President Obama during the President's joint address to Congress in September 2009. President Obama did not lie. What would Mr. Wilson's best defense against the President's claim that he was defamed?

1. President Obama is a public figure and can't bring defamation suits

2. Mr. Wilson is a public figure and can't bring defamation suits

3. That "You Lie" is not a defamatory statement

4. That Mr. Wilson is speaking on the floor of the House and protected by an absolute privilege

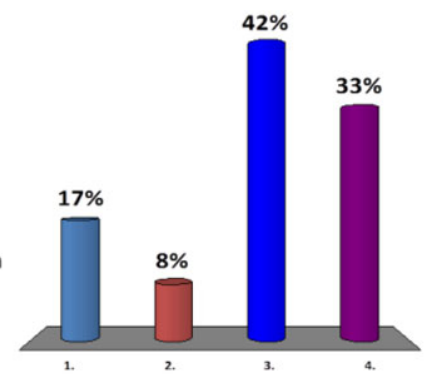

Figure 4: Possible Defenses to the Tort of Defamation

\section{Scenario for next 3 slides}

- Bob is driving from one mowing job to the next

- He texts his roommate to ask about their plans to go to a tailgate party before the game on Saturday morning

- He isn't watching where he's going, runs a red light, and smashes into Tom's car

- Tom and his car are hurt

Figure 5: Liability for Torts Committed by a Partner Scenario

Without exception, a majority of Legal Environment students answer the first two questions (Figures 6 and 7) correctly. However, these results change significantly on the final, more difficult question, which asks about a different partner's liability for Bob's tort (see Figure 8).

As Figure 8 indicates, the last time this question was presented to Professor Park's Legal Environment students, only 35 percent answered it correctly. When the answer indicator revealed the correct answer, an immediate hum arose in the classroom as students expressed their surprise and, for some, their disappointment. Over the course of several semesters, these results 
Bob is personally liable to Tom because of his tort.

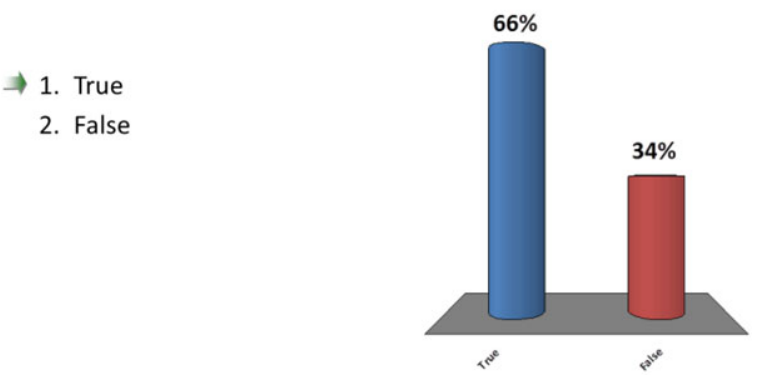

Figure 6: Slide 1 - Liability for Torts Committed by a Partner

The ABC Partnership is liable to Tom because of Bob's tort.

1. True
2. False

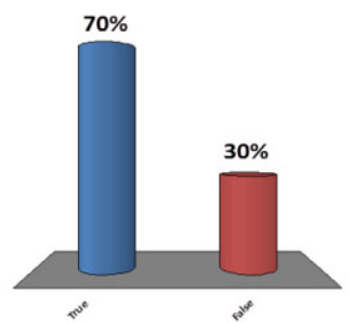

Figure 7: Slide 2 - Liability for Torts Committed by a Partner

Charlie is personally liable to Tom because of Bob's tort.

$\rightarrow 1$. True

2. False

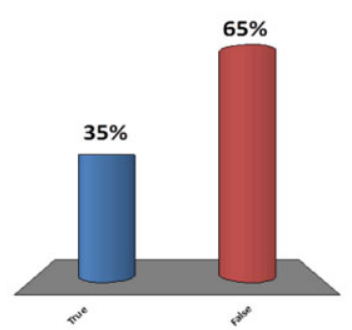

Figure 8: Slide 3 - Liability for Torts Committed by a Partner 
provided Professor Park with specific, useful information about student misunderstanding of this concept that she had not gained in her previous eleven years of teaching through simple lecture. ${ }^{71}$ Her students themselves also indicate that this process is valuable. ${ }^{72}$

This process, which is particularly useful when teaching topics instructors know in advance are complex and require more time to learn, is an example of what Lincoln refers to as "asking increasingly difficult questions." Difficult questions also offer an excellent opportunity to introduce peer instruction (sometimes referred to as "think-pair-share"), which generally allows students to learn from each other, as well as the instructor, and also articulate what they know to their fellow students. Peer instruction begins with the introduction of a question, followed by small group discussion, response to the question via clickers, display of the responses (without the correct answer), instructor-moderated class discussion on the question, which could include individual rationale for the chosen answers, followed by repolling of the same question. ${ }^{74}$

Referring to the above example regarding tort liability in a partnership, Professor Park uses a form of peer instruction ${ }^{75}$ to help students learn the concept about individual partners' liability for a partnership debt created by another partner (which she has identified through clicker use as a difficult question for students). To begin, she includes in the presentation two identical slides that ask the third question in the series, which is typically answered incorrectly. After students answer the first slide and the results are displayed (with no answer provided), she asks students to discuss their response with one or two students sitting around them. After a few minutes of discussion, the second identical question is displayed, and then the results of the two questions are compared. The responses on the second slide typically improve.

\footnotetext{
${ }^{71}$ See Caron \& Gely, supra note 4, at 29.

${ }^{72}$ Results of the informal Clicker Survey administered to numerous students in Professor Park's Legal Environment of Business Class indicate that a large majority of the 374 students who completed the survey either strongly agreed (49 percent) or agreed (38 percent) that they "do more thinking during clicker sessions than in regular lecture sessions." A majority also strongly agreed (66 percent) or agreed (24 percent) that clicker questions help them know how well they are learning the material. See Clicker Survey, infra Appendix (Table 2: Clicker Survey).

${ }^{73}$ Lincoln, supra note 40 , at 38.

${ }^{74} I d$. at 29 .

${ }^{75}$ Levey uses a very similar version of think-pair-share to teach business law. See Levey, supra note 5 , at 5 .
} 
Generally, Professor Park's experience watching the students engage in this process is that most of them become highly invested in the answer. ${ }^{76}$

One use of clickers that has proven quite popular with students in Professor Farag's Business Law I and II courses is an exercise she calls "You Be the Judge." Using this technique, Professor Farag starts her lecture with a relevant case or fact pattern. After giving the key facts, students are polled about how they should rule. Once polled, Professor Farag will delay revealing the results of the "court's" holding until mid- or postlecture, at which time the students are repolled first to see if their answers remain the same. For instance, when the class covers contract consideration, Professor Farag leads with the Upper Deck Baseball Card case $^{77}$ in which the plaintiff, attorney Anthony Passante, was promised 3 percent of Upper Deck stock from a grateful board of directors as a thank you for securing a company-saving $\$ 100,000$ loan. The board later reneged on the promise, and Passante sued for the value of 3 percent of stock, at that time worth $\$ 33$ million. When placed in the position of getting to vote as a decision maker, students are much more interested in the outcome. In the Upper Deck Baseball Card case, students most often side with the plaintiff's position in the initial polling and then, after an explanation of bargained-for exchange and past consideration, a majority often will shift sides when polled a second time.

A nice option the Turning Technology polling software offers is the ability to display a slide that compares the results of the same question asked at different points in the presentation. Professor Farag will often use comparison slides in the "You Be the Judge" exercise. In one such exercise in Business Law II, students read a fact pattern involving the concept of risk of loss for merchants and nonmerchants under the UCC. After answering the same question twice during the presentation, the resulting comparison slide looked like Figure 9.

This slide shows that on the first polling, student opinion was divided between three of the four answers, with only 33 percent voting for the correct answer on the first attempt. On the second poll occurring postlecture, 100 percent of the students responded correctly. Comparison slides such as this are a useful tool for the instructor to see if students comprehend the lecture

\footnotetext{
${ }^{76}$ This process also contributes toward building a sense of community. See infra text accompanying notes $87-88$.

${ }^{77}$ Passante v. McWilliams, 62 Cal. Rptr. 2d 298 (1997).
} 


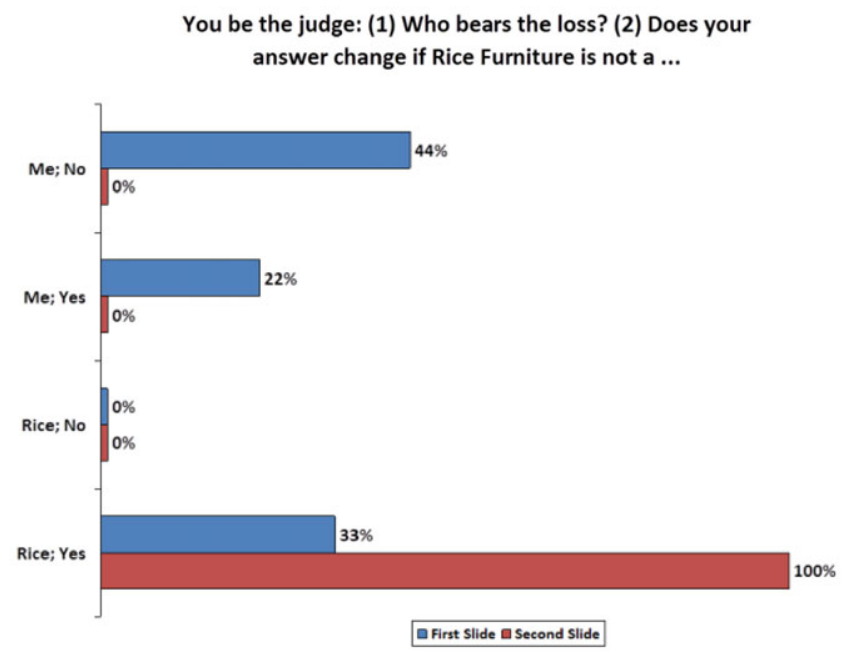

Figure 9: You Be the Judge

material. They also allow students to see their individual learning progress as well as that of the class as a whole.

Content-focused questions such as these are also easily described as student-focused, which we cover in the next section. They often give students an opportunity to talk with each other about their answers and also give students feedback about their understanding of the material. ${ }^{78}$

\section{B. Student-Focused Clicker Use}

In addition to encouraging students to learn course content and engage in critical thinking, clickers can also help promote a sense of community in the classroom. Clickers foster a student's confidence in his or her learning and ability to improve. They can also help students develop their views of the world and themselves by asking them to consider their own opinions about particular topics. Asking questions regarding students' opinions in particular can also stimulate interesting classroom discussion and, to bring it full circle, add to the sense of community and sharing in the classroom.

\footnotetext{
${ }^{78}$ The questions discussed in this section fit within the category that Salemi refers to as "are-youwith-me" questions. Salemi, supra note 52, at 391-92.
} 


\section{Encouraging student opinion and classroom discussion}

"[S]ampling student opinions can be a useful tool for motivating student interest and for gauging the impact of a presentation." 79 Students pay attention to questions that ask their opinions because they are interested in how the other students will respond. ${ }^{80}$ These questions are also valuable because they indicate the instructor's interest in how students think. ${ }^{81}$

Professor Farag makes a special effort to use clicker slides to solicit student opinions and stimulate student discussion when covering ethics. For this topic, Professor Farag informs students that their responses will remain anonymous, which the literature supports as increasing participation. ${ }^{82} \mathrm{Stu}-$ dents are polled on a series of questions such as "Is it unfair to move into better (open) seats at a sporting event or a concert?" After students register their responses with clickers, they are given the opportunity to discuss their answers. In Professor Farag's experience, even some of the more passive students may be willing to participate in discussions when they realize that other students share their conclusion.

\section{Determining student confidence levels}

Before each of the three exams in her Legal Environment courses, Professor Park holds an exam review session using clickers. At the beginning of each of these sessions, students respond to the first slide (see Figure 10), which asks them to identify their confidence regarding the exam.

Students answer the same question at the end of the exam review session, and then see the results of both questions presented in a comparison slide (see Figure 11).

As the above comparison slide indicates, student confidence levels rise significantly based upon their participation in the review session. These

\footnotetext{
${ }^{79}$ Id. at 389.

${ }^{80} I d$. at 390.

${ }^{81} I d$.

${ }^{82}$ See Kay \& LeSage, supra note 9, at 821 ("Anonymity allows all students to be active members of the classroom community and participate in the learning process without recrimination."). See also Caldwell, supra note 12, at 11.
} 


\section{I feel confident regarding this exam.}

1. Strongly agree

2. Slightly agree

3. Slightly disagree

4. Strongly disagree

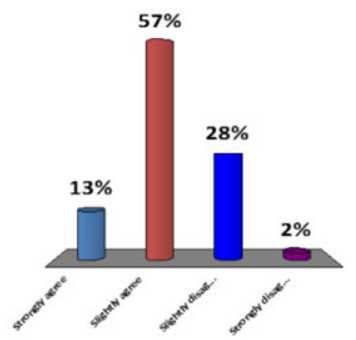

Figure 10: Sample Confidence Level Slide

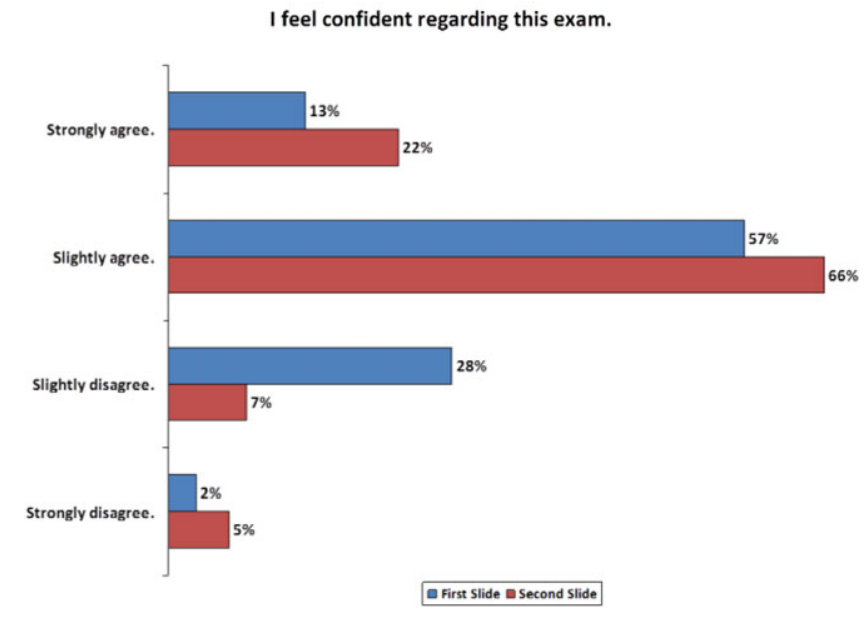

Figure 11: Confidence Level Comparison Slide

results indicate that students are engaged in the material presented and that the review sessions are valuable to them. ${ }^{83}$

\footnotetext{
${ }^{83}$ The clicker exam review sessions may also have the additional benefit of motivating students to step up their studies if they were among those whose confidence level decreased after the session ended.
} 


\section{Immediate feedback}

Clickers are especially effective as an easy, efficient way of giving students immediate feedback on their thinking. This can be done in many different ways, as Caron explains:

There are several approaches to providing feedback to students, including midterm (or more frequent) examinations, writing exercises, peer critiques, and introspective journals. Although each of these techniques has some value, and may be particularly well-suited for particular situations, none give feedback that is at once prompt, specific, and summative. The CPS [classroom performance system], in contrast, fulfills all three of these objectives without imposing undue demands on faculty time. Students receive immediate feedback on their level of understanding of each day's materials. The feedback is specific, as it identifies answers to particular questions. Finally, feedback allows the student to identify areas of weakness and seek assistance for further development. ${ }^{84}$

Our experience indicates that students highly value the feedback they gain from clickers. In the first semester in which Professor Park began using clickers, she conducted a Mid-Semester Assessment (MAP) to begin the process of gauging whether the use of clickers was effective. ${ }^{85}$ This is an excerpt from the report related to student attitudes about clickers:

While very unusual, each group and over $70 \%$ of the fostering learning comments were on a single topic-learning activities. Students reported many different aspects that helped them learn, but clearly they believe that what they do in class fosters learning. Some (over two-thirds) indicated that they [believe the] clicker slides promote learning. Students indicated that they get to hear a case, make a decision, then learn whether or not they made the right call. But beyond being right or wrong, students indicated that they learn a great deal from the discussion that followed the slide as to why the correct answer was correct and the incorrect answer was incorrect. ${ }^{86}$

\footnotetext{
${ }^{84}$ Caron \& Gely, supra note 4, at 28-29.

${ }^{85}$ The Boise State University Center for Teaching and Learning (CTL) provides a Mid-Semester Assessment Process (MAP) to any instructor wishing to "gauge how and what students are learning and to assess his/her teaching. A MAP involves a CTL consultant who meets with students in a class to collect their thoughts about the course and then meets with the instructor to discuss student responses." See Mid-Semester Assessment Process (MAP) for Classroom Courses, Boise State University Center for Teaching \& Learning, http://ctl.boisestate.edu/services/indivconsult/map (last visited Mar. 11, 2014).
}

${ }^{86}$ MAP for Professor Park_GB 202, March 9, 2010_10:40 am (Spring 2010) (on file with author). 


\section{What is your major?}
A. Accounting
B. Economics
C. Finance
D. Management
E. Marketing
F. Other/Undecided

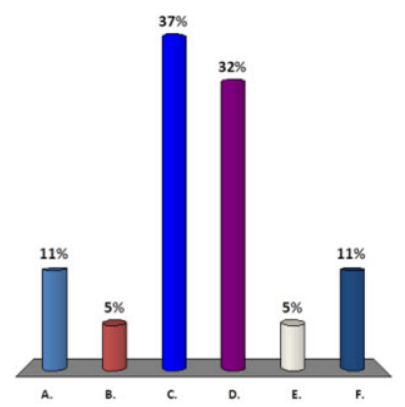

Figure 12: Sample Survey Slide

\section{Creating a sense of community}

Easton notes that one reason for using clickers is to foster a sense of community and shared learning experience. ${ }^{87}$ In addition to the examples previously discussed (all of which add to creating a sense of community in the classroom), clickers can be used in countless other ways to help students engage in the material and with each other-and have fun in the process.

On the first day of her Business Law I classes, Professor Farag posts survey slides asking about student majors, extracurricular activities, and travel experiences to learn more about her students and to encourage them to learn more about each other. An illustration of one survey slide is presented in Figure 12.

Professor Farag also uses introductory games to help familiarize students with clickers and create a sense of fun in the classroom. For example, in her Business Law II course, Professor Farag presents an ice breaker clicker slide containing a word scramble on one of the topics to be covered in class (see Figure 13).

In her Legal Environment of Business courses, Professor Park occasionally plays music in the classroom while setting up the computer for the presentation. On those days, one of the first clicker slides presented will be a question

\footnotetext{
${ }^{87}$ Easton, supra note 2 , at 6.
} 


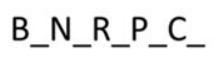

1. EUMFG

2. OLAJJ

;) AYKTU

4. $A Z Y U F$

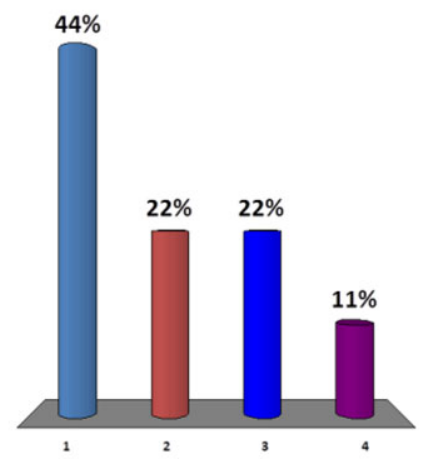

Figure 13: Sample Ice-breaker Slide

about the music such as the musician or the name of the song. ${ }^{88}$ A majority of the students polled agreed that beginning class in this way is a good idea.

Each of the uses described in this section contributes to an overall student preference for courses in which clickers are used. ${ }^{89}$ Additionally, slides like these used in the beginning of class actually serve two purposes. They help students understand that learning with clickers can be fun, and they also give students immediate, no-stakes practice with using them. As instructors in the classroom, we also enjoy these fun sessions and thus become part of the learning community created in the classroom. As such, this is an example of how the student-focused slides overlaps with the benefits instructors can also gain by using clickers.

\footnotetext{
${ }^{88}$ The idea for playing music in the classroom comes from Professor Mark DeAngelis, Assistant Professor at University of Connecticut, who writes the Legal Studies Classroom blog. See Legal Studies Classroom Blog, http://legalstudiesclassroom.blogspot.com/ (last visited Mar. 11, 2014). Levey, supra note 5, uses a similar exercise in which he asks students their favorite Tom Cruise movie late in class because "we need the education equivalent of an intermission in some class sessions." Id. at 5 .

${ }^{89}$ See Easton, supra note 2, at 7. Eighty-eight percent of Professor Park's students who completed the Clicker Survey either strongly agreed (64 percent) or agreed (24 percent) with this statement: "Given two class sections that are the same in all other respects, I would prefer the section that uses clickers." See infra Appendix (Table 2: Clicker Survey).
} 


\section{A. Instructor-Focused Clicker Use}

Our third category of clicker use is instructor-focused use. In addition to teaching course content with clickers and using clickers to create a sense of community and building student self-confidence, this final section in our framework explains how clickers can be used as a classroom management and assessment tool. It concludes with suggestions from the literature for other ways that faculty can use clickers effectively.

\section{Classroom management}

Instructors who use TurningPoint clickers have the advantage of using the software to take roll each day without any additional effort. Each student who attends class with a properly registered clicker ${ }^{90}$ signifies his or her presence simply by using the clicker during that session. After class, instructors can download that information in a report (along with other information regarding the presented slides, such as correct answers, who left class early, etc.). ${ }^{91}$

Clickers can also help instructors manage and resolve early classroom issues such as determining which students have attended class for administrative purposes, learning the number of students who have not purchased textbooks, helping with clicker registration issues, or reminding students to check their e-mail regularly. Professor Park has also used clicker slides to help with decisions regarding assessment. For example, she has asked students their opinion about whether a recently graded exam was fair (see Figure 14).

\footnotetext{
${ }^{90}$ The Blackboard LMS provides a TurningPoint registration tool that students can use to register their clicker, thus allowing integration between the software and Blackboard. Instructors download the student's registration information into the TurningPoint software, which then associates the student's clicker ID number with that particular student during classroom polling. See generally "Registering a Clicker or Copy of Responseware in Blackboard (Students) http://oit.boisestate.edu/learning/student-response-system/registering-clickercopy-responseware-blackboard-students/ (last visited Dec. 5, 2014).

${ }^{91}$ After a polling session is completed and the data is saved on the instructor's computer, TurningPoint offers a variety of different reports that can be run, depending on what type of information is desired. Reports can be organized according to participant, by individual questions, by demographics, and even by comparing data to result in a comparison report. See generally TurningPoint UserGuide 5.2 for PC, at http:/ / www.turningtechnologies.com/trainingsupport/user-guides (last visited Mar. 11, 2014). TurningPoint also offers a number of tutorial videos regarding reports and other features of the software. See generally New TurningPoint 5 Training Tutorials, http://www.turningtechnologies.com/tutorials (last visited Mar. 11, 2014).
} 
I thought the exam was:

1. Too easy
2. Just easy enough
3. Of medium difficulty
4. Hard, but fair
5. Too hard

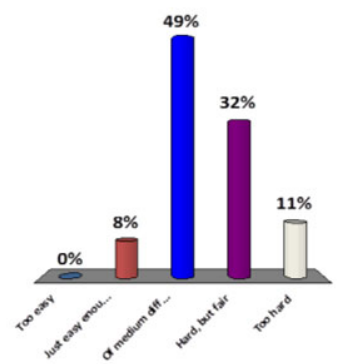

Figure 14: Sample Slide Regarding Assessment

She has also asked students whether they would prefer to take an online exam in the testing center as opposed to paper tests in the classroom. Professor Park also saves a lot of time in grading by using clickers to provide feedback on homework and exams at one time to the entire class, rather than individually for each student.

\section{Assessment}

Clickers can be a helpful tool to ensure student accountability. According to Easton, the literature suggests positive findings regarding the use of clicker technology to "assess student engagement with set tasks and recommended reading." "92 To encourage her students to engage in the material prior to class, at the beginning of each class Professor Farag administers a ten-question multiple choice clicker quiz that covers the assigned reading. Students who answer nine or ten questions correctly receive one point. Students have access to the questions and answers prior to class, although the order of how the questions and answers appear on the clicker quiz are altered. While the prelecture clicker quizzes do not ensure that students will always complete the chapter reading prior to class, they do provide an incentive for students to at least partially engage with the material prior to lecture. In addition to the instant feedback given the students and the instructor at the time of the clicker quiz, another advantage to using clickers rather than paper and pen

\footnotetext{
${ }^{92}$ Easton, supra note 2 , at 4.
} 
tests to administer the prelecture quizzes is that the results are automatically graded and ready to be downloaded in a course learning management system such as Blackboard Learn.

\section{Other possible uses}

Using clickers well in class can have a positive impact on student teaching evaluations. ${ }^{93}$ Salemi also proposed games and simulations ${ }^{94}$ and gathering discipline-specific data ${ }^{95}$ as other possible uses of clickers. The most recent version of the TurningPoint software offers a variety of intriguing new ways to use clickers, including team and individual competitions based upon fastest responses, correct responses, and even wagering. ${ }^{96}$ Harlow et al. also report that "[s]ome instructors were planning novel ideas, for example incorporating animations, graphs and math tools to teach various concepts such as gamer theory (e.g., prisoner's dilemma) or half-life (science fiction computer game viewed from the perspective of the player)." ${ }^{97}$

\footnotetext{
${ }^{93}$ A review of student appraisals of Professor Farag's classes since incorporating clickers in 2011 indicates that all references to clickers or clicker usage were either neutral or positive, with no negative feedback received. This is a representative quote from an anonymous student: "This is the first class using the clickers, and they were great. . . It's great to take the polls in class so you really know quickly what you need to look up." Survey, Linfield College: Student Appraisal of Instruction (Fall 2012) (on file with author). While no direct correlation can be established between clicker use and student appraisal rankings, Professor Farag's ratings on "facilitates involvement" increased measurably after the first semester using clickers in the classroom, from 3.67 to 3.81 on a four-point Likert scale. Professor Park's teaching evaluations from students also confirm strong student preference for clickers. Since students began using clickers in her classes, an overwhelming number of them have indicated on evaluations that the use of clickers was one of the most valuable aspects of their learning experience. Not one student has commented negatively about their use. Comment Summary, Boise State University Teaching Evaluation Summary (Fall 2012) (on file with author).

${ }^{94}$ Salemi, supra note 52, at 398-99.

${ }^{95} I d$. at 395 (data collection enhances student engagement by raising their interest in the topic and providing them an opportunity to ask "What is going on?"). See also Angel Hoekstra \& Stefanie Mollborn, How Clicker Use Facilitates Existing Pedagogical Practices in Higher Education: Data from Interdisciplinary Research on Student Response Systems, 37 Learning, Media \& Tech. 303 (2012) ("In some disciplines, collecting real-time, anonymous data from students offers a powerful tool for testing hypotheses and spurring group discussion.”).

${ }^{96}$ See generally TurningPoint UserGuide 5.2 for PC and New TurningPoint 5 Training Tutorials, supra note 91.

${ }^{97}$ Harlow et al., supra note 56, at 3.
} 
"On-the-fly" (or contingent) teaching is another interesting possibility.

Contingent teaching is a method of teaching that depends on the actions of students, rather than on a fixed sequence that the instructor predetermines. For example, if student understanding seems low, the instructor then adjusts what happens next and likely revisits prior material and/or probes to find the underlying cause of misunderstanding. The main benefit here is that clickers provide a sense of where the whole class stands, not just those students who are willing to raise their hands and visually admit they do not understand something. One study conducted prior to the advent of clickers estimated that about $10 \%$ of all students in a given classroom accounted for $75 \%$ of the interaction.). ${ }^{98}$

Contingent teaching requires expertise with the software and a willingness to take risks in the classroom, which many instructors are reluctant to do. ${ }^{99}$ However, if done properly, contingent teaching allows instructors to take advantage of those "teachable moments" that arise unexpectedly in the classroom and revise presentation of the material as needed.

We have found that this three-part focus is a useful framework in our legal studies courses. Our collective experience (ours and our students') is similar to that of faculty and students in other disciplines. Generally, our students report increased engagement and interest in the material, which we have observed to be true. Our own engagement in and enjoyment of teaching has also improved dramatically. However, the process to get to this point was sometimes rocky. We both learned through trial and error, making many small mistakes along the way, some of which may have been avoidable had we had advice or specific tips from other legal studies faculty using clickers. We hope that the previous examples help others in our discipline learn. Below, we identify some additional challenges new clicker users might face and provide tips and suggestions for overcoming them. Hence, the purpose of this next part is to offer our suggestions for specific methods to help other legal studies instructors make the transition.

\footnotetext{
${ }^{98}$ Lincoln, supra note 40, at 28. See also Easton, supra note 2, at 9 ("A lecturer prepared to adapt lecture delivery to seize upon a 'teachable moment' determined through clicker use can, by revising a concept in a different manner, employ this situation to great pedagogical advantage.").

${ }^{99}$ Lincoln, supra note 40 , at 38 . Even given our experience with clickers, neither of us has, as yet, used on-the-fly questions in the classroom.
} 


\section{Challenges And Tips}

Although many faculty indicate that the use of clickers in their classrooms is beneficial, mastering the technology and learning to write appropriate questions can be a challenging process, especially in the beginning. The technology may also pose problems for students, as well as the added cost of purchasing a clicker or a license to use the software on a smart device. We believe that the benefits gained by using clickers are well worth the time spent in the beginning. However, our experience mirrors that of other faculty, who routinely report that the disadvantages of clicker use are the administrative burdens and extra time needed to learn to use them effectively. ${ }^{100}$ Below we discuss these and other challenges, offering useful tips to help faculty overcome them.

\section{Technology}

Fortunately, the technology is not difficult to master. ${ }^{101}$ This is certainly true in our experience with TurningPoint, especially if one is already familiar with PowerPoint since TurningPoint builds from that. ${ }^{102}$ Professor Park was fortunate enough to attend an afternoon training session and also had institutional support. ${ }^{103}$ Linfield College has fewer resources for faculty desiring to adopt clicker technology. Professor Farag received some assistance from her institution's Director of Educational Technology about clicker system selection and initial setup but was largely self-taught on how to use TurningPoint software. ${ }^{104}$

\footnotetext{
${ }^{100}$ Harlow et al., supra note 56. See also Easton, supra note 2, at 13; Beatty, supra note 8; Shapiro, supra note 45 .

${ }^{101}$ See DeBourgh, supra note 56, at 86.

${ }^{102}$ Although this article suggests that learning the technology is not necessarily difficult, of course that depends upon one's technological prowess.

${ }^{103}$ See Boise State University "Teaching with Clickers" webpage, http://oit.boisestate.edu/ learning/student-response-system/teaching-with-clickers/ (last visited Dec. 5, 2014). Available resources include links to TurningPoint tutorials, case studies on clickers, YouTube videos, and articles on clicker use.

${ }^{104}$ See TurningTechnologies Training website, http://www.turningtechnologies.com/trainingsupport (last visited Mar. 11, 2014). Professor Farag learned to use clickers by referring to these online tutorials, articles from other teaching and learning centers from other institutions, and by trial and error.
} 
Other practical start-up issues include clicker registration, receiver use, and wireless connections. In institutions where students purchase their own clickers, ${ }^{105}$ one common start-up issue new faculty should be aware of is learning how to instruct students on registering their clicker information within the applicable learning management system (such as Blackboard) so that individual student responses may be recorded. ${ }^{106}$ On occasion, individual clickers will not work in class, due to either user error or issues with the device. ${ }^{107}$ In class, faculty must ensure that they insert the clicker receiver into the computer USB drive in order for the software to record student responses. Also, faculty must remember to select the "participant list" for that particular section, or else all answers will be recorded anonymously. For students using their smart devices rather than a clicker, a reliable wireless connection is necessary. (Also, the instructor must register a unique password for the semester with TurningTechnologies so that students may log in for each session.)

TIP: Try out the technology in an empty classroom at least once before the term begins. $^{108}$

Some instructors who do not permit laptops or smart devices in the classroom may require that students purchase a clicker rather than a license that allows them to participate in polling with their phones. "As one professor noted, smartphone use 'got to the point of being distracting, not only to the

\footnotetext{
${ }^{105}$ See infra text accompanying notes 125-28 for further discussion about costs associated with purchasing clickers and about Linfield College's decision to purchase a set of clickers rather than require students to purchase them. Some institutions or programs purchase clickers for student use.
}

${ }^{106}$ See supra note 13. See also Barnett, supra note 32, at 477 (reporting that students had trouble registering their clickers, including issues with the registration system and reading the font on the registration codes). For an example of a training tutorial regarding registering clickers, see the Boise State Tutorials and Technical Help (Faculty), http://at.boisestate.edu/clickers/faculty/technical-help/ (last visited Mar. 11, 2014).

${ }^{107}$ See, e.g., Barnett, supra note 32, at 478 (listing several issues regarding clicker reliability, including worn out batteries, a software "glitch," and clickers going into sleep mode).

${ }^{108}$ See, e.g., Premkumar \& Coupal, supra note 34, at 147 ("You should become familiar with all the features available in the software. . . It is easier to input questions ahead of time and test them. . . . You should be comfortable with the software functions you intend to employ prior to using them during your class. Our experience has been that if the instructor fumbles with the technology trying to get something to work, it causes disruption and impatience among the students. This makes it that much harder to engage (or re-engage) them in the remainder of the topics."). 
person using it but to multiple people in the classroom.' Hardware clickers solve this dilemma." 109

Instructors are also advised to experiment with the reports TurningTechnologies makes available. "The rich data that are recorded during class sessions create opportunities for analysis at many levels: individual responses to specific questions, response trends for students working in teams, scores on clicker quizzes and exams, and question item-response statistics." 110 Learning the technology well also opens up a variety of teaching opportunities of which faculty may be unaware such as learning to use clickers to ask "on-the-fly" questions in class as the opportunities arise. ${ }^{111}$

TIP: Introduce clickers into the classroom gradually and wait to assign points for student clicker use until the technology is mastered. This approach will also allow the instructor to experiment with the many ways in which clickers can be used without fear of failing or losing important student data. ${ }^{112}$

\section{Drafting questions and covering material}

"The art of designing effective questions is deceptively non-trivial and can be time-consuming for an instructor new to [clickers]." ${ }^{113}$ Indeed, drafting slides is an ongoing process that may begin with a steep learning curve. Several authors who have written on drafting clicker questions stress the importance

\footnotetext{
${ }^{109}$ Perry Binder, The Intersection of Ethical Decision-Making Modules and Classroom Response Systems in Business Education, Future Educ. Conf. Proc.-Libreriauniversitaria.it Edizioni (2013).

${ }^{110}$ DeBourgh, supra note 56, at 86 .

${ }^{111}$ See, Premkumar \& Coupal, supra note 34, at 147 (suggesting that instructors who want to add new clicker questions during class should know how to use the software). See also supra notes 98-99 and accompanying text. Other interactive slides faculty might be interested in include competitions, demographics, picture slides, and priority ranking slides. See Boise State University "Tutorials and Technical Help (Faculty)," supra note 107.

${ }^{112}$ See, e.g., Salemi, supra note 52, at 401 ("First, instructors must design or redesign their lectures to allow for clicker activities. It is not sufficient simply to make space for clicker activities. It is necessary to organize or reorganize material in a way that exploits the educational benefits of using a CRS [classroom response systems] .... Second, instructors must create clicker activities. Here, I recommend a gradual approach. New users can begin by writing a few are-you-with-me questions for each lecture. They can next choose a few lectures were polling student opinion makes sense. They can then choose some lectures where peer instruction would help students better understand difficult but important concepts and write more challenging questions for peer instruction activities.").
}

${ }^{113}$ Beatty, supra note 8 , at 6 . 
of understanding their pedagogical goals first. For instance, Lincoln suggests that "effective use of clicker technology requires faculty members to first develop their course goals, including learning outcomes such as what students should know and be able to do at the end of the course."114 After that, instructors can then decide how to execute those course goals through the use of clickers and structure the learning environment accordingly. ${ }^{115}$

TIP: Start small when incorporating clicker slides in your lecture. Even two to three clicker slides in a lecture can be beneficial in the beginning. Over time an instructor can gradually expand his or her use of the variety and types of clicker slides that are used.

Learning the types of questions to ask and where to place them within the class is also a skill professors will develop over time. ${ }^{116}$

TIP: Review your slides well before class so that you will recognize the flow and remember what slides are yet to come.

Faculty who begin using clickers also report that they are left with less time in the classroom to cover all the material in the class, which poses the challenge Easton refers to as the "pressure to cover content." 117 However, Easton and others stress that the benefits of using clickers, including "increased participation and engagement" 118 and better awareness of student understanding, ${ }^{119}$ outweigh the additional time needed to learn and master them.

\footnotetext{
${ }^{114}$ Lincoln, supra note 40, at 27. See also Premkumar \& Coupal, supra note 34, at 147.

${ }^{115}$ Lincoln, supra note 40 , at 27.

${ }^{116}$ See DeBourgh, supra note 56, at 81 ("Teachers commonly underestimate how often they ask questions in classroom settings. Posing questions too frequently can result in cognitive overload."). See also supra notes 69-78 and accompanying text for discussion of how we learned, over time, that slides that ask students to apply the law to a factual scenario were more valuable than those that asked general concepts. Professor Park's students indicated in surveys that they appreciated the opportunity to make a decision about a case and then learn whether they made the right call. See supra note 72 and accompanying text.

${ }^{117}$ Easton, supra note 2, at 10. Other possible constraints that Easton mentions are "lecture theatre management" and "fear of technology." Id. See also Caldwell, supra note 12, at 14.

${ }^{118}$ Easton, supra note 2, at 10.

${ }^{119}$ Elliott, supra note 67, at 82-83. See also Caldwell, supra note 12, at 14.
} 
TIP: Provide students with a list of terms or a lecture outline of material that will not be covered in class. ${ }^{120}$

\section{Lack of institutional support}

In 2004, Beatty wrote, "At some universities, [clicker] support can get lost in the cracks, falling within neither the customary purview of traditional classroom technology support (handled by an audio-visual department) nor traditional computer and network support (handled by central IT). Highlevel policy directives may be required." ${ }^{121}$ In the years since, we hope that clicker use has become more common and, with it, the necessary support and training. ${ }^{122}$ In any event, choosing a platform that provides good support is recommended. ${ }^{123}$

TIP: If your institution has not adopted an official clicker, seek input from others, including other faculty adopters on campus, and the institutional offices providing technical support and classroom technology.

\section{Cost to students}

This is the most common negative aspect of clickers identified by students. "A majority of clicker users feel that students do mind the economic costs associated with buying and using clickers." 124 Because TurningPoint is the clicker technology supported by Boise State University, most students will enroll in several classes in which they can use the same clicker, so the cost is spread out over time and seems more easily affordable. Students also have the option of purchasing a less expensive license that they can activate and

\footnotetext{
${ }^{120}$ See, e.g., Caldwell, supra note 12, at 14. Professor Park provides students with a list of those topics they are responsible for learning outside of class and also tries to cover them briefly in exam review sessions. Also, we each provide students with a student version of the clicker slides we presented in class after each topic has been covered.

${ }^{121}$ Beatty, supra note 8 , at 7 .

${ }^{122}$ Professor Park has certainly seen this evolution at Boise State University, which provides a plethora of institutional support. Although Professor Farag did not have quite this level of support at Linfield College, she was able to find resources from Turning Technologies, which has a fairly robust website and many reps that can provide support.

${ }^{123}$ See DeBourgh, supra note 56, at 86. See also Lincoln, supra note 40, at 27 (suggesting that becoming a "champion" of clickers in individual departments maybe useful).

${ }^{124}$ Lincoln, supra note 40 , at 38 .
} 
then use on their smart devices instead of purchasing a clicker. ${ }^{125}$ Professor Farag, whose classes are smaller, was able to get her business department to purchase a set of clickers for her courses. ${ }^{126}$ A particular clicker is assigned to each student for their use during the semester, but the clickers remain with the instructor. This is an attractive alternative for instructors who teach only a few smaller sections.

TIP: If it is not feasible for your institution or department to acquire the clickers for use in your classroom, make sure that you use the clickers on a regular basis so that students feel their clickers were worth the cost. ${ }^{127}$

\section{Student objections}

Other than the initial cost, the "[c]hallenges for students in courses employing classroom clickers are minimal. Students learn to operate the clicker itself without difficulty as most contemporary college-age students were born in an era where use of computer and communications technologies have always been part of their lives." 128 Nonetheless, some students report that they simply do not like using clickers. ${ }^{129}$

TIP: Explaining how clicker use can benefit students and how it supports your class goals improves students' attitudes toward using clickers. $^{130}$

\footnotetext{
125 See supra notes 11 and 109 and accompanying text for additional discussion about purchasing a license.

${ }^{126}$ In our experience, students do not appreciate having to purchase a clicker if they will not have the opportunity to use it in other courses. Professor Farag solved this issue by asking her department to agree to fund the initial cost, approximately $\$ 1,300$, of the set of thirty-five TurningPoint clickers and receiver. The department then recouped the cost by assessing a $\$ 10$ per student fee over the course of a year. Current students pay no fees for the use of the clickers. Similarly, the MBA program at Boise State paid for a set of clickers to use in Professor Park's MBA course since she is currently the only MBA faculty who uses them in class.

${ }^{127}$ See DeBourgh, supra note 56, at 86; Lincoln, supra note 40, at 38.

${ }^{128}$ DeBourgh, supra note 56 , at 86.

${ }^{129}$ See, e.g., Caldwell, supra note 12, at 15-16 (reporting that student negative reactions to clickers include losing the devices, technical problems, the instructor's lack of experience, and the idea of "forcing" students to pay attention).

${ }^{130}$ Easton, supra note 2, at 7; Lincoln, supra note 40, at 38.
} 


\section{Cheating}

Any time points are awarded for clicker use in the classroom, the potential for cheating exists. ${ }^{131}$ For instance, in situations where students receive credit for registering their attendance via clicker or where participation points are awarded for responding to a certain number of slides, the temptation exists that an absent student might request that a friend click in on his or her behalf. This would be especially easy to do in courses with larger enrollments.

TIP: Limit the amount of points that can be earned by clickers to a minimal amount, say 5 percent, so students have less incentive to cheat with their clickers. Add a section in your syllabus that clearly communicates to students that using a classmate's clicker, for any reason, is cheating.

\section{Privacy and confidentiality issues}

Students report that they appreciate responding to some questions anonymously. "Students said that clicker questions asking about anonymous but highly personal information (e.g., past sexual experiences or drug use) were often the most interesting, memorable, and useful questions for learning in sociology." 132 However, questions that ask students their opinions about controversial or personal matters can cause students concern over whether the responses will remain private. For some students, instructors need to take care to always include a response option that offers participation credit for those who prefer not to respond. ${ }^{133}$

TIP: In those few instances where a clicker question is of a sensitive nature, the instructor can (1) either assure the students that the underlying data will not be looked at, (2) toggle the polling software from identifiable to anonymous, or (3) include a "prefer not to answer" response option that still allows credit for students who wish not respond. ${ }^{134}$

Despite all of these challenges, we have concluded that the benefits of transitioning our classrooms to be more interactive through the use of

\footnotetext{
${ }^{131}$ See Caldwell, supra note 12, at 17 (reporting on a survey in which 20 to 58 percent of students reported seeing incidents of cheating with clickers).

${ }^{132}$ Mollborn \& Hoekstra, supra note 51, at 25.

${ }^{133}$ Id.

${ }^{134} I d$.
} 
clickers far outweigh the costs. Many other faculty have reached a similar conclusion. In fact, Salemi believes that personal response systems represent a major transformation in teaching.

Indeed, it is my view that the current generation of CRS [classroom response systems] is the most important advancement in education technology to occur in the past 30 years. I hold this view because, unlike no other technology, the use of clickers allows the instructor to create two-way communication in classes of several hundred. With clickers, it is possible to prompt students in ways that keep them engaged. Before clickers, it might have been possible for a talented lecturer to hold student attention but it would have been difficult for that same lecturer to help students move from passively listening to actively thinking about the presented ideas. ${ }^{135}$

\section{Future Research}

The opportunities for additional research regarding the use of clickers in legal studies courses are many, both empirical and otherwise. The following avenues of further research may relate to undergraduate courses, MBA courses, or a combination of both. Professor Park's survey of Legal Environment of Business students indicates that clickers were not effective in giving students incentive to study the material outside of class. ${ }^{136}$ Additional research that explores how clickers could be used to increase engagement outside of the classroom would add to the body of literature, as would research regarding the potential for using clickers as a formal assessment tool. ${ }^{137}$ Trees and Jackson suggest that further research could be done to consider "what elements of the learning environment are likely to impact the success of clickers." 138 There is currently little research regarding the different technologies

\footnotetext{
${ }^{135}$ Salemi, supra note 52, at 401-02. See also Lincoln, supra note 40, at 36-37; DeBourgh, supra note 56 , at 86 .

${ }^{136}$ See infra Appendix (Table 1: Engagement Survey). Although a majority of surveyed students agree that they came to class better prepared (37 percent strongly agree, 34 percent agree), the answers to questions about whether clickers encourage students to prepare for class and participate in class discussion are more spread out over all the choices. Only 40 percent of the students related clicker use to looking over notes outside of class and staying caught up on the reading. This is also true regarding a relationship between clicker use in the classroom and making the material relevant outside of class or applying it to students' lives.

${ }^{137}$ Elliott, supra note 67 , at 86 .

${ }^{138}$ Trees \& Jackson, supra note 48, at 25.
} 
available to poll students, so a comparison of the strengths and weaknesses of clicker-based polling and online or mobile polling would be an interesting and useful addition to the body of knowledge about clicker use. Finally, given the increasing importance that the AACSB (and perhaps other accrediting bodies) place upon outcomes assessment, research that measures student retention rates of material presented with classes that used clickers, as opposed to those that do not, would be of interest.

\section{Conclusion}

Our decision to begin using clickers in the classroom was one of the best decisions we have made regarding our teaching. Our students are now more engaged in our classrooms and in the material. We find ourselves thinking much more about new approaches to try in our classroom and now have a much better understanding that deep thinking alone is not enough. Deep planning is also required. An unintended reward of working to introduce clickers into our classrooms is that our renewed interest in teaching has increased our desire to be more involved in campus life and in our professional organizations. We are also more engaged, not only in the classroom, but outside of it as well, in our departments, across our campuses, and in our professional lives.

\section{Appendix: Legal Environment of Business Survey RESULTS}


Table 1: Engagement Survey

\begin{tabular}{|c|c|c|c|c|c|}
\hline $\begin{array}{l}\text { Question: To what extent do } \\
\text { the following behaviors, } \\
\text { thoughts, and feelings describe } \\
\text { you in Legal Environment of } \\
\text { Business (GB 202) during the } \\
\text { semester? }\end{array}$ & $\begin{array}{l}\text { Very } \\
\text { Characteristic } \\
\text { of } M e\end{array}$ & $\begin{array}{c}\text { Characteristic } \\
\text { of } \mathrm{Me}\end{array}$ & $\begin{array}{l}\text { Moderately } \\
\text { Characteristic } \\
\text { of } M e\end{array}$ & $\begin{array}{l}\text { Not Really } \\
\text { Characteristic } \\
\text { of } M e\end{array}$ & $\begin{array}{l}\text { Not at All } \\
\text { Characteristic } \\
\text { of } M e\end{array}$ \\
\hline $\begin{array}{l}\text { Raising my hand to ask a } \\
\text { question during class }\end{array}$ & $\begin{array}{l}8 \% \\
(39)\end{array}$ & $\begin{array}{l}13 \% \\
(68)\end{array}$ & $\begin{array}{l}24 \% \\
(123)\end{array}$ & $\begin{array}{c}37 \% \\
(190)\end{array}$ & $\begin{array}{l}18 \% \\
(94)\end{array}$ \\
\hline $\begin{array}{l}\text { Participating actively in } \\
\text { class discussions }\end{array}$ & $\begin{array}{l}9 \% \\
(45)\end{array}$ & $\begin{array}{l}21 \% \\
(109)\end{array}$ & $\begin{array}{l}31 \% \\
(160)\end{array}$ & $\begin{array}{l}31 \% \\
(161)\end{array}$ & $\begin{array}{l}8 \% \\
(39)\end{array}$ \\
\hline $\begin{array}{l}\text { Asking questions when I } \\
\text { don't understand }\end{array}$ & $\begin{array}{l}9 \% \\
(48)\end{array}$ & $\begin{array}{l}28 \% \\
(144)\end{array}$ & $\begin{array}{l}32 \% \\
(167)\end{array}$ & $\begin{array}{l}24 \% \\
(121)\end{array}$ & $\begin{array}{l}7 \% \\
(34)\end{array}$ \\
\hline $\begin{array}{l}\text { Doing all the assigned } \\
\text { homework }\end{array}$ & $\begin{array}{l}58 \% \\
(297)\end{array}$ & $\begin{array}{l}29 \% \\
(147)\end{array}$ & $\begin{array}{l}12 \% \\
(60)\end{array}$ & $\begin{array}{l}2 \% \\
(8)\end{array}$ & $\begin{array}{l}-1 \% \\
(2)\end{array}$ \\
\hline Coming to class every day & $\begin{array}{l}53 \% \\
(274)\end{array}$ & $\begin{array}{l}30 \% \\
(156)\end{array}$ & $\begin{array}{l}11 \% \\
(59)\end{array}$ & $\begin{array}{l}4 \% \\
(19)\end{array}$ & $\begin{array}{l}1 \% \\
(6)\end{array}$ \\
\hline $\begin{array}{l}\text { Going to the professor's } \\
\text { office hours to review my } \\
\text { work or to ask questions }\end{array}$ & $\begin{array}{l}4 \% \\
(21)\end{array}$ & $\begin{array}{l}8 \% \\
(40)\end{array}$ & $\begin{array}{l}28 \% \\
(144)\end{array}$ & $\begin{array}{l}39 \% \\
(203)\end{array}$ & $\begin{array}{l}21 \% \\
(107)\end{array}$ \\
\hline $\begin{array}{l}\text { Thinking about the course } \\
\text { between class meetings }\end{array}$ & $\begin{array}{l}19 \% \\
(98)\end{array}$ & $\begin{array}{l}42 \% \\
(216)\end{array}$ & $\begin{array}{l}30 \% \\
(154)\end{array}$ & $\begin{array}{l}7 \% \\
(36)\end{array}$ & $\begin{array}{l}2 \% \\
(10)\end{array}$ \\
\hline $\begin{array}{l}\text { Finding ways to make the } \\
\text { course interesting to me }\end{array}$ & $\begin{array}{l}17 \% \\
(85)\end{array}$ & $\begin{array}{l}41 \% \\
(211)\end{array}$ & $\begin{array}{c}32 \% \\
(165)\end{array}$ & $\begin{array}{l}8 \% \\
(42)\end{array}$ & $\begin{array}{l}2 \% \\
(11)\end{array}$ \\
\hline $\begin{array}{l}\text { Reading the materials } \\
\text { posted on Blackboard }\end{array}$ & $\begin{array}{l}23 \% \\
(120)\end{array}$ & $\begin{array}{l}32 \% \\
(164)\end{array}$ & $\begin{array}{l}30 \% \\
(156)\end{array}$ & $\begin{array}{l}11 \% \\
(59)\end{array}$ & $\begin{array}{l}3 \% \\
(15)\end{array}$ \\
\hline $\begin{array}{l}\text { Bringing my clicker to class } \\
\text { and participating in the } \\
\text { posted clicker questions }\end{array}$ & $\begin{array}{l}84 \% \\
(430)\end{array}$ & $\begin{array}{l}12 \% \\
(60)\end{array}$ & $\begin{array}{l}4 \% \\
(19)\end{array}$ & $\begin{array}{l}1 \% \\
(4)\end{array}$ & $\begin{array}{l}-1 \% \\
(1)\end{array}$ \\
\hline Taking good notes in class & $\begin{array}{l}42 \% \\
(216)\end{array}$ & $\begin{array}{l}31 \% \\
(161)\end{array}$ & $\begin{array}{l}19 \% \\
(98)\end{array}$ & $\begin{array}{l}4 \% \\
(23)\end{array}$ & $\begin{array}{l}3 \% \\
(16)\end{array}$ \\
\hline Listening carefully in class & $\begin{array}{l}50 \% \\
(255)\end{array}$ & $\begin{array}{l}39 \% \\
(201)\end{array}$ & $\begin{array}{l}10 \% \\
(52)\end{array}$ & $\begin{array}{l}1 \% \\
(5)\end{array}$ & $\begin{array}{l}-1 \% \\
(1)\end{array}$ \\
\hline $\begin{array}{l}\text { Looking over class notes } \\
\text { between classes to be } \\
\text { sure I understand } \\
\text { the material }\end{array}$ & $\begin{array}{l}15 \% \\
(76)\end{array}$ & $\begin{array}{l}25 \% \\
(130)\end{array}$ & $\begin{array}{l}35 \% \\
(179)\end{array}$ & $\begin{array}{l}22 \% \\
(111)\end{array}$ & $\begin{array}{l}4 \% \\
(18)\end{array}$ \\
\hline $\begin{array}{l}\text { Really desiring to learn the } \\
\text { material }\end{array}$ & $\begin{array}{l}27 \% \\
(139)\end{array}$ & $\begin{array}{l}41 \% \\
(212)\end{array}$ & $\begin{array}{l}24 \% \\
(125)\end{array}$ & $\begin{array}{l}6 \% \\
(32)\end{array}$ & $\begin{array}{l}1 \% \\
(6)\end{array}$ \\
\hline $\begin{array}{l}\text { Being confident I can learn } \\
\text { and do well in the class }\end{array}$ & $\begin{array}{l}33 \% \\
(172)\end{array}$ & $\begin{array}{l}44 \% \\
(224)\end{array}$ & $\begin{array}{l}19 \% \\
(99)\end{array}$ & $\begin{array}{l}3 \% \\
(15)\end{array}$ & $\begin{array}{l}1 \% \\
(4)\end{array}$ \\
\hline Putting forth effort & $\begin{array}{l}39 \% \\
(203)\end{array}$ & $\begin{array}{l}44 \% \\
(226)\end{array}$ & $\begin{array}{l}15 \% \\
(78)\end{array}$ & $\begin{array}{l}1 \% \\
(5)\end{array}$ & $\begin{array}{l}-1 \% \\
(2)\end{array}$ \\
\hline Being organized & $\begin{array}{l}37 \% \\
(191)\end{array}$ & $\begin{array}{l}42 \% \\
(217)\end{array}$ & $\begin{array}{l}16 \% \\
(84)\end{array}$ & $\begin{array}{l}3 \% \\
(16)\end{array}$ & $\begin{array}{l}1 \% \\
(6)\end{array}$ \\
\hline
\end{tabular}


Table 1: Continued

\begin{tabular}{|c|c|c|c|c|c|}
\hline $\begin{array}{l}\text { Question: To what extent do } \\
\text { the following behaviors, } \\
\text { thoughts, and feelings describe } \\
\text { you in Legal Environment of } \\
\text { Business (GB 202) during the } \\
\text { semester? }\end{array}$ & $\begin{array}{l}\text { Very } \\
\text { Characteristic } \\
\text { of } M e\end{array}$ & $\begin{array}{l}\text { Characteristic } \\
\text { of } \mathrm{Me}\end{array}$ & $\begin{array}{l}\text { Moderately } \\
\text { Characteristic } \\
\text { of } \mathrm{Me}\end{array}$ & $\begin{array}{l}\text { Not Really } \\
\text { Characteristic } \\
\text { of } \mathrm{Me}\end{array}$ & $\begin{array}{c}\text { Not at All } \\
\text { Characteristic } \\
\text { of } \mathrm{Me}\end{array}$ \\
\hline Getting a good grade & $\begin{array}{l}35 \% \\
(179)\end{array}$ & $\begin{array}{l}46 \% \\
(236)\end{array}$ & $\begin{array}{l}15 \% \\
(79)\end{array}$ & $\begin{array}{l}4 \% \\
(18)\end{array}$ & $\begin{array}{l}-1 \% \\
(2)\end{array}$ \\
\hline Doing well on the tests & $\begin{array}{l}26 \% \\
(136)\end{array}$ & $\begin{array}{l}44 \% \\
(224)\end{array}$ & $\begin{array}{l}20 \% \\
(105)\end{array}$ & $\begin{array}{l}8 \% \\
(41)\end{array}$ & $\begin{array}{l}2 \% \\
(8)\end{array}$ \\
\hline Staying up on reading & $\begin{array}{l}13 \% \\
(67)\end{array}$ & $\begin{array}{l}27 \% \\
(141)\end{array}$ & $\begin{array}{l}39 \% \\
(202)\end{array}$ & $\begin{array}{l}17 \% \\
(87)\end{array}$ & $\begin{array}{l}3 \% \\
(18)\end{array}$ \\
\hline Having fun in class & $\begin{array}{l}25 \% \\
(126)\end{array}$ & $\begin{array}{l}41 \% \\
(209)\end{array}$ & $\begin{array}{l}26 \% \\
(135)\end{array}$ & $\begin{array}{l}7 \% \\
(35)\end{array}$ & $\begin{array}{l}2 \% \\
(9)\end{array}$ \\
\hline Helping fellow students. & $\begin{array}{l}16 \% \\
(82)\end{array}$ & $\begin{array}{l}37 \% \\
(190)\end{array}$ & $\begin{array}{l}33 \% \\
(170)\end{array}$ & $\begin{array}{l}10 \% \\
(51)\end{array}$ & $\begin{array}{l}4 \% \\
(22)\end{array}$ \\
\hline $\begin{array}{l}\text { Making sure to study on a } \\
\text { regular basis }\end{array}$ & $\begin{array}{l}10 \% \\
(54)\end{array}$ & $\begin{array}{l}34 \% \\
(174)\end{array}$ & $\begin{array}{l}40 \% \\
(205)\end{array}$ & $\begin{array}{l}14 \% \\
(72)\end{array}$ & $\begin{array}{c}2 \% \\
(10)\end{array}$ \\
\hline $\begin{array}{l}\text { Finding ways to make the } \\
\text { course material relevant } \\
\text { to my life }\end{array}$ & $\begin{array}{l}24 \% \\
(125)\end{array}$ & $\begin{array}{l}42 \% \\
(216)\end{array}$ & $\begin{array}{l}26 \% \\
(134)\end{array}$ & $\begin{array}{c}6 \% \\
(31)\end{array}$ & $\begin{array}{l}2 \% \\
(8)\end{array}$ \\
\hline $\begin{array}{l}\text { Applying course material } \\
\text { to my life } \\
\text { Total responding }=\mathbf{5 1 5}\end{array}$ & $\begin{array}{l}26 \% \\
(132)\end{array}$ & $\begin{array}{l}43 \% \\
(220)\end{array}$ & $\begin{array}{l}25 \% \\
(126)\end{array}$ & $\begin{array}{c}6 \% \\
(29)\end{array}$ & $\begin{array}{l}1 \% \\
(7)\end{array}$ \\
\hline
\end{tabular}

This survey was adapted from the Student Course Engagement Questionnaire (SCEQ) discussed in depth by Handlesman, Briggs, Sullivan, and Towler in their article A Measure of College Student Course Engagement, 98 J. Educ. Res. 184 (Jan./Feb. 2005). This survey was administered to Legal Environment of Business students over the course of five semesters between 2010 and 2012. 
Table 2: Clicker Survey

\begin{tabular}{|c|c|c|c|c|c|}
\hline $\begin{array}{l}\text { Question: Please rate your level of agreement with } \\
\text { the following statements about clicker use in your } \\
\text { class: }\end{array}$ & $\begin{array}{l}\text { Strongly } \\
\text { Agree }\end{array}$ & $\begin{array}{l}\text { Somewhat } \\
\text { Agree }\end{array}$ & Neutral & $\begin{array}{l}\text { Somewhat } \\
\text { Disagree }\end{array}$ & $\begin{array}{l}\text { Strong } \\
\text { Disagree }\end{array}$ \\
\hline $\begin{array}{l}\text { Using clickers gives me immediate feedback } \\
\text { about my understanding of a concept }\end{array}$ & $\begin{array}{l}73 \% \\
(272)\end{array}$ & $\begin{array}{l}24 \% \\
(90)\end{array}$ & $\begin{array}{l}2 \% \\
(9)\end{array}$ & $\begin{array}{l}1 \% \\
(2)\end{array}$ & $\begin{array}{c}-1 \% \\
(1)\end{array}$ \\
\hline $\begin{array}{l}\text { Clicker questions help me to know how well } \\
\text { I am learning the material }\end{array}$ & $\begin{array}{l}69 \% \\
(257)\end{array}$ & $\begin{array}{l}26 \% \\
(99)\end{array}$ & $\begin{array}{l}4 \% \\
(14)\end{array}$ & $\begin{array}{l}1 \% \\
(3)\end{array}$ & $\begin{array}{c}-1 \% \\
(1)\end{array}$ \\
\hline $\begin{array}{l}\text { Clicker questions help me prepare for } \\
\text { exams in this class }\end{array}$ & $\begin{array}{l}66 \% \\
(245)\end{array}$ & $\begin{array}{l}24 \% \\
(91)\end{array}$ & $\begin{array}{l}8 \% \\
(29)\end{array}$ & $\begin{array}{l}2 \% \\
(7)\end{array}$ & $\begin{array}{l}1 \% \\
(2)\end{array}$ \\
\hline $\begin{array}{l}\text { I choose my answer to each clicker question } \\
\text { carefully }\end{array}$ & $\begin{array}{l}45 \% \\
(167)\end{array}$ & $\begin{array}{l}44 \% \\
(166)\end{array}$ & $\begin{array}{l}9 \% \\
(32)\end{array}$ & $\begin{array}{l}2 \% \\
(8)\end{array}$ & $\begin{array}{l}-1 \% \\
(1)\end{array}$ \\
\hline $\begin{array}{l}\text { I pay attention to whether or not my answer } \\
\text { to a clicker question is right or wrong }\end{array}$ & $\begin{array}{l}84 \% \\
(316)\end{array}$ & $\begin{array}{l}12 \% \\
(46)\end{array}$ & $\begin{array}{l}3 \% \\
(11)\end{array}$ & $\begin{array}{l}0 \% \\
(0)\end{array}$ & $\begin{array}{l}-1 \% \\
(1)\end{array}$ \\
\hline $\begin{array}{l}\text { Clicker questions encourage me to be more } \\
\text { engaged in the classroom process }\end{array}$ & $\begin{array}{l}72 \% \\
(271)\end{array}$ & $\begin{array}{l}22 \% \\
(81)\end{array}$ & $\begin{array}{l}5 \% \\
(19)\end{array}$ & $\begin{array}{l}1 \% \\
(3)\end{array}$ & $\begin{array}{l}0 \% \\
(0)\end{array}$ \\
\hline I actively participate during class & $\begin{array}{l}57 \% \\
(212)\end{array}$ & $\begin{array}{l}25 \% \\
(93)\end{array}$ & $\begin{array}{l}15 \% \\
(57)\end{array}$ & $\begin{array}{l}2 \% \\
(9)\end{array}$ & $\begin{array}{l}1 \% \\
(3)\end{array}$ \\
\hline $\begin{array}{l}\text { The use of clickers helps my experience in } \\
\text { this class to be more like the experience } \\
\text { of a small class }\end{array}$ & $\begin{array}{c}50 \% \\
(187)\end{array}$ & $\begin{array}{c}30 \% \\
(113)\end{array}$ & $\begin{array}{l}14 \% \\
(53)\end{array}$ & $\begin{array}{l}5 \% \\
(18)\end{array}$ & $\begin{array}{l}1 \% \\
(3)\end{array}$ \\
\hline $\begin{array}{l}\text { Using clickers helps me to identify } \\
\text { misunderstandings and misconceptions } \\
\text { in my thinking while in class }\end{array}$ & $\begin{array}{l}59 \% \\
(219)\end{array}$ & $\begin{array}{c}30 \% \\
(113)\end{array}$ & $\begin{array}{l}9 \% \\
(35)\end{array}$ & $\begin{array}{l}1 \% \\
(4)\end{array}$ & $\begin{array}{l}1 \% \\
(3)\end{array}$ \\
\hline $\begin{array}{l}\text { Using clickers encourages me to really } \\
\text { understand the material rather than just } \\
\text { recognizing the correct answer }\end{array}$ & $\begin{array}{c}47 \% \\
(176)\end{array}$ & $\begin{array}{c}35 \% \\
(132)\end{array}$ & $\begin{array}{l}14 \% \\
(53)\end{array}$ & $\begin{array}{c}3 \% \\
(10)\end{array}$ & $\begin{array}{l}1 \% \\
(3)\end{array}$ \\
\hline $\begin{array}{l}\text { I prefer the more traditional lecture } \\
\text { approach rather than the clicker } \\
\text { approach }\end{array}$ & $\begin{array}{l}7 \% \\
(28)\end{array}$ & $\begin{array}{c}7 \% \\
(27)\end{array}$ & $\begin{array}{l}18 \% \\
(68)\end{array}$ & $\begin{array}{c}33 \% \\
(122)\end{array}$ & $\begin{array}{c}34 \% \\
(129)\end{array}$ \\
\hline $\begin{array}{l}\text { I do more thinking during clicker sessions } \\
\text { than in regular lecture sessions }\end{array}$ & $\begin{array}{l}49 \% \\
(184)\end{array}$ & $\begin{array}{l}38 \% \\
(143)\end{array}$ & $\begin{array}{l}10 \% \\
(36)\end{array}$ & $\begin{array}{l}2 \% \\
(8)\end{array}$ & $\begin{array}{l}1 \% \\
(3)\end{array}$ \\
\hline $\begin{array}{l}\text { Using clickers encourages me to come to } \\
\text { class better prepared }\end{array}$ & $\begin{array}{l}37 \% \\
(137)\end{array}$ & $\begin{array}{l}34 \% \\
(126)\end{array}$ & $\begin{array}{l}20 \% \\
(74)\end{array}$ & $\begin{array}{l}8 \% \\
(30)\end{array}$ & $\begin{array}{l}2 \% \\
(7)\end{array}$ \\
\hline $\begin{array}{l}\text { Given two class sections that are the same in } \\
\text { all other respects, I would prefer the } \\
\text { section that uses clickers } \\
\text { Total responding }=\mathbf{3 7 4}\end{array}$ & $\begin{array}{l}64 \% \\
(241)\end{array}$ & $\begin{array}{l}24 \% \\
(91)\end{array}$ & $\begin{array}{l}8 \% \\
(31)\end{array}$ & $\begin{array}{l}2 \% \\
(6)\end{array}$ & $\begin{array}{l}1 \% \\
(5)\end{array}$ \\
\hline
\end{tabular}

To gather additional information about clickers, Professor Park developed and administered this survey one semester after first administering the Engagement Survey. The Clicker Survey was administered to students over the course of four semesters between 2010 and 2012. 